\title{
Cultural Resources Assessment of a Historic Cistern (41GU211) Inadvertent Discovery for the Medlin Street Police Parking Lot Project, City of Seguin, Guadalupe County, Texas
}

Steven Sarich

Josh Haefner

Follow this and additional works at: https://scholarworks.sfasu.edu/ita

Part of the American Material Culture Commons, Archaeological Anthropology Commons, Environmental Studies Commons, Other American Studies Commons, Other Arts and Humanities Commons, Other History of Art, Architecture, and Archaeology Commons, and the United States History Commons

Tell us how this article helped you.

This Article is brought to you for free and open access by the Center for Regional Heritage Research at SFA ScholarWorks. It has been accepted for inclusion in Index of Texas Archaeology: Open Access Gray Literature from the Lone Star State by an authorized editor of SFA ScholarWorks. For more information, please contact cdsscholarworks@sfasu.edu. 


\section{Cultural Resources Assessment of a Historic Cistern (41GU211) Inadvertent Discovery for the Medlin Street Police Parking Lot Project, City of Seguin, Guadalupe County, Texas \\ Creative Commons License \\ (c) (1) \& 8}

This work is licensed under a Creative Commons Attribution-NonCommercial 4.0 International License 


\section{Cultural Resources Assessment of a Historic Cistern (41GU211) Inadvertent Discovery for the Medlin Street Police Parking Lot Project, City of Seguin, Guadalupe County, Texas}

By:

Steven Sarich and Josh Haefner

Texas Antiquities Permit No. 9169

TRC Technical Report No. 315751.1000

Prepared for:

City of Seguin

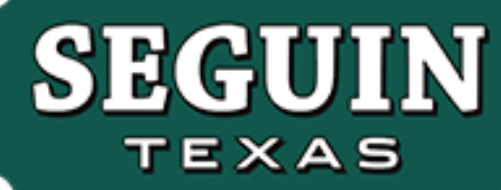

Prepared by:

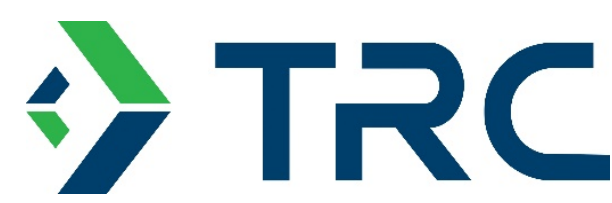

December 2019 
This page intentionally left blank. 


\title{
Cultural Resources Assessment of a Historic Cistern (41GU211) Inadvertent Discovery for the Medlin Street Police Parking Lot Project, City of Seguin, Guadalupe County, Texas
}

\author{
By: \\ Steven Sarich and Josh Haefner
}

Prepared for:

City of Seguin

205 North River Street

Seguin, Texas 78155

\author{
Prepared by: \\ TRC Environmental Corporation \\ 505 East Huntland Drive, Suite 250 \\ Austin, Texas 78752
}

Texas Antiquities Permit No. 9169

Principal Investigator: Josh Haefner

TRC Technical Report No. 315751.1000

December 2019 
This page intentionally left blank. 


\section{TABLE OF CONTENTS}

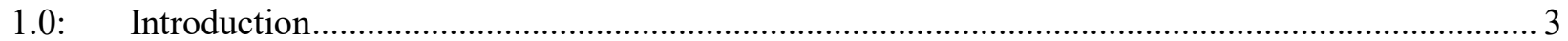

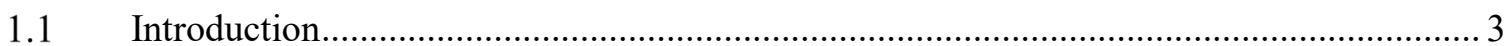

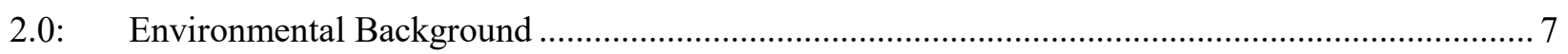

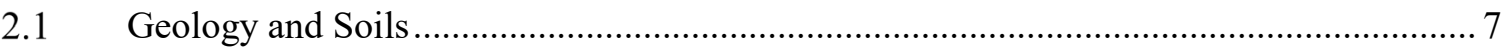

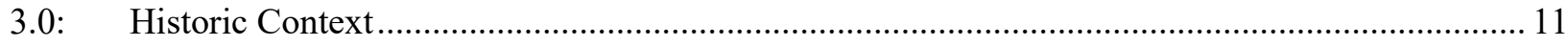

3.1 Guadalupe County and the City of Seguin (1535 to Present) …..................................... 11

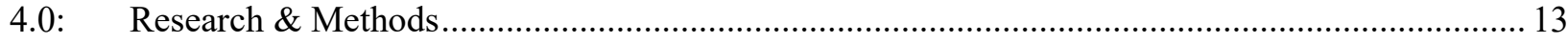

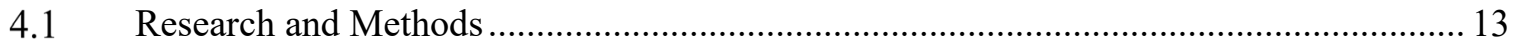

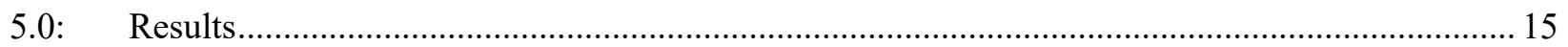

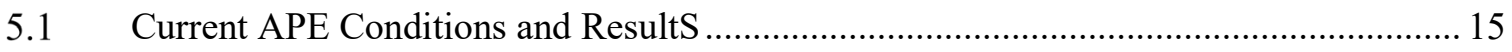

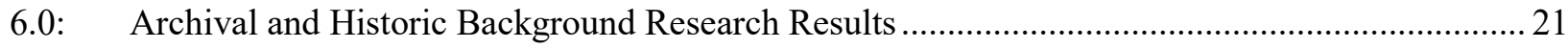

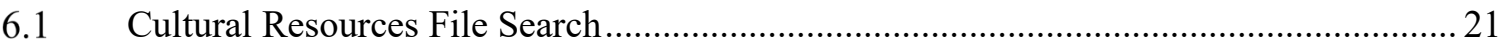

6.2 Archival and Historic Research of Tract with Cistern ................................................... 25

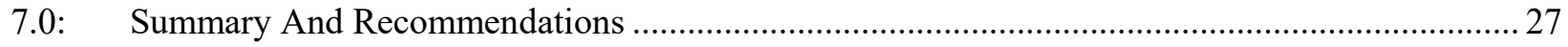

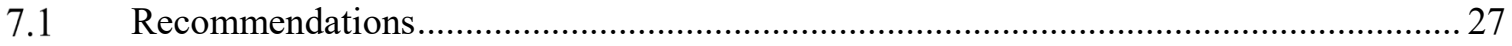

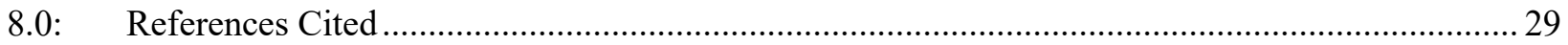




\section{LIST OF FIGURES}

Figure 1. Parking Lot APE Location on Seguin, Texas 7.5' Topographic Quadrangle Map...................... 5

Figure 2. Parking Lot APE Location on Aerial Photograph. ................................................................ 6

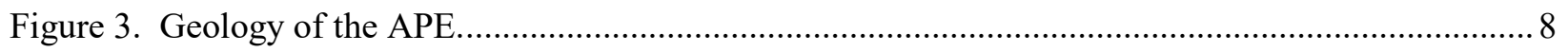

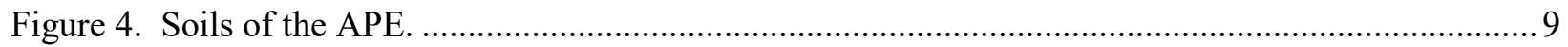

Figure 5. Overview of Parking Lot Location and Existing Construction Activities, Facing South........... 15

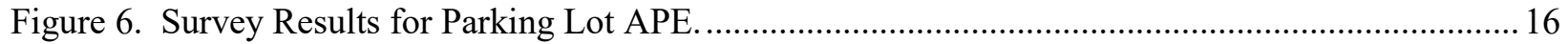

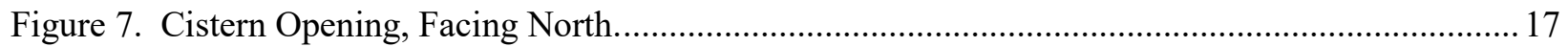

Figure 8. Cut Limestone Brick Lining Cistern, Facing North. .......................................................... 17

Figure 9. Cistern Interior with Accumulated Gravel at the Bottom, Facing North................................. 18

Figure 10. Ceramic Drainage Pipe in South Wall, Facing South....................................................... 18

Figure 11. Red Brick Fragment West of Cistern Opening, Facing North................................................. 19

Figure 12. Red Brick Fragment East of Cistern Opening, Facing North............................................. 19

Figure 13. Overview of Single Grave Marker Location with Construction Fencing, Facing Southeast. . 20

Figure 14. Closeup of Single Grave Marker, Facing North..............................................................20

Figure 15. Cultural Resources and Previous Surveys within 1-Mile of the APE. ...................................22

\section{LIST OF TABLES}

Table 1. Previously Conducted Archeological Surveys Within a 1-Mile Radius of the APE...................2 21

Table 2. Previously Recorded Cultural Resources Within a 1-Mile Radius of the APE .........................223

\section{LIST OF APPENDICES}

Appendix A: Design Plans

Appendix B: TPWD Internal Communication

Appendix C: Historic Resources Background Review 


\section{0: INTRODUCTION}

\section{$1.1 \quad$ INTRODUCTION}

In November 2019, under contract with the City of Seguin (the City), TRC Environmental Corporation (TRC) conducted in field documentation of an inadvertent discovery consisting of a cistern (41GU211) identified in October 2019. The cistern was discovered during active construction of an asphalt parking lot for the Seguin City Police Department, located within the City of Seguin, Guadalupe County, Texas. Additionally, the City identified a single grave marker prior to construction located in the northwest corner of the Area of Potential Effects (APE), defined as the approximately 0.50 -acre proposed parking lot. This area was also visually surveyed by TRC cultural personnel to ensure that it was avoided during construction activities. In tandem with this effort, TRC cultural personnel conducted archival research consisting of a review of the Texas Historical Commission Archeological Sites-Atlas (THC-Atlas) for the tract of land on which the inadvertent discovery/cistern is located.

According to current design plans, the City is constructing an asphalt parking lot located at the northeast corner of the intersection of Medlin Street and North Saunders Street and will be approximately 0.50 acres in size (Figures 1 and 2). Proposed impacts include razing of existing standing structures, clearing of vegetation and litter-debris, grading of the parking lot location, the construction of a 700 -square foot detention pond ( 2.5 feet deep), the repair of an existing drainage ditch and the installation of 42 feet of highdensity polyethylene pipe, a sidewalk ramp for pedestrian crossing of Medlin Street, and associated new curb and sidewalk installation. With the exception of the detention pond which will be 2.5 feet deep, vertical impacts will be less a foot in depth (Appendix A: Design Plans). The project will expand parking facilities for the Seguin City Police Department. The inadvertent discovery/cistern was found during active grading of the parking lot location, at which point all construction work was halted, and through TRC's engineering department, TRC cultural personnel were contacted. TRC cultural personnel coordinated with the THC to make a determination if the inadvertent discovery would require survey, obtain an emergency permit for the project, and determine if construction could proceed (Appendix B: THC Correspondence).

As the inadvertent discovery/cistern is located on lands under purview of an entity of the State of Texas, the project is subject to compliance with the Antiquities Code of Texas (ACT). During coordination with the THC it was determined that the inadvertent discovery/cistern would require documentation and recording, and an emergency Texas Antiquities Permit number 9169 was assigned to the Medlin Street Police Parking Lot project on November 12, 2019. Data regarding results of TRC's project area visit and cistern documentation was sent to the THC on November 14, 2019 and the THC coordinated via email that construction could resume (Appendix B: THC Correspondence). Archeological fieldwork consisted of an examination and documentation of the feature, inspection of the entirety of the work site for additional features and artifacts, and documentation of the above-noted grave marker. Subsequent to the field survey, TRC cultural personnel conducted additional archival and historic sources research related to the tract of land on which the inadvertent discovery/cistern and grave marker is located. Archival and historic sources that were reviewed include property deed records at the Guadalupe County Clerk's Office and family histories and genealogical information courtesy of the Seguin Public Library. The purpose of these investigations was to evaluate the eligibility of the identified resource for listing in the National Register of Historic Places per Section 106 (36 CRF 800) of the National Preservation Act of 1966, as amended, or for designation as a State Antiquities Landmark (13 TAC 26.12) No artifacts were collected during this 
investigation; all records will be permanently curated at the Center for Archaeological Studies in San Marcos, Texas. 


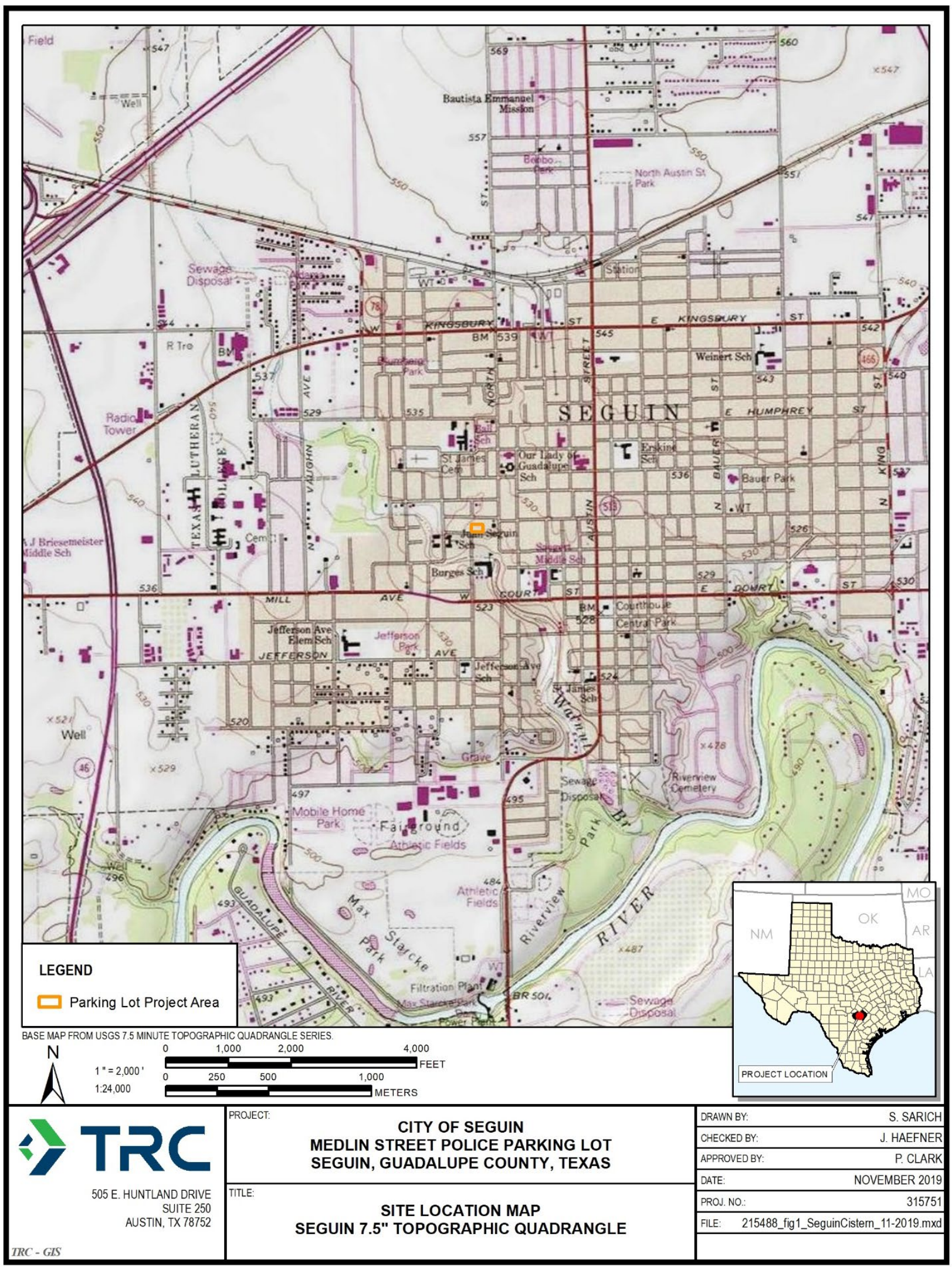

Figure 1. Parking Lot APE Location on Seguin, Texas 7.5' Topographic Quadrangle ㅍap. 


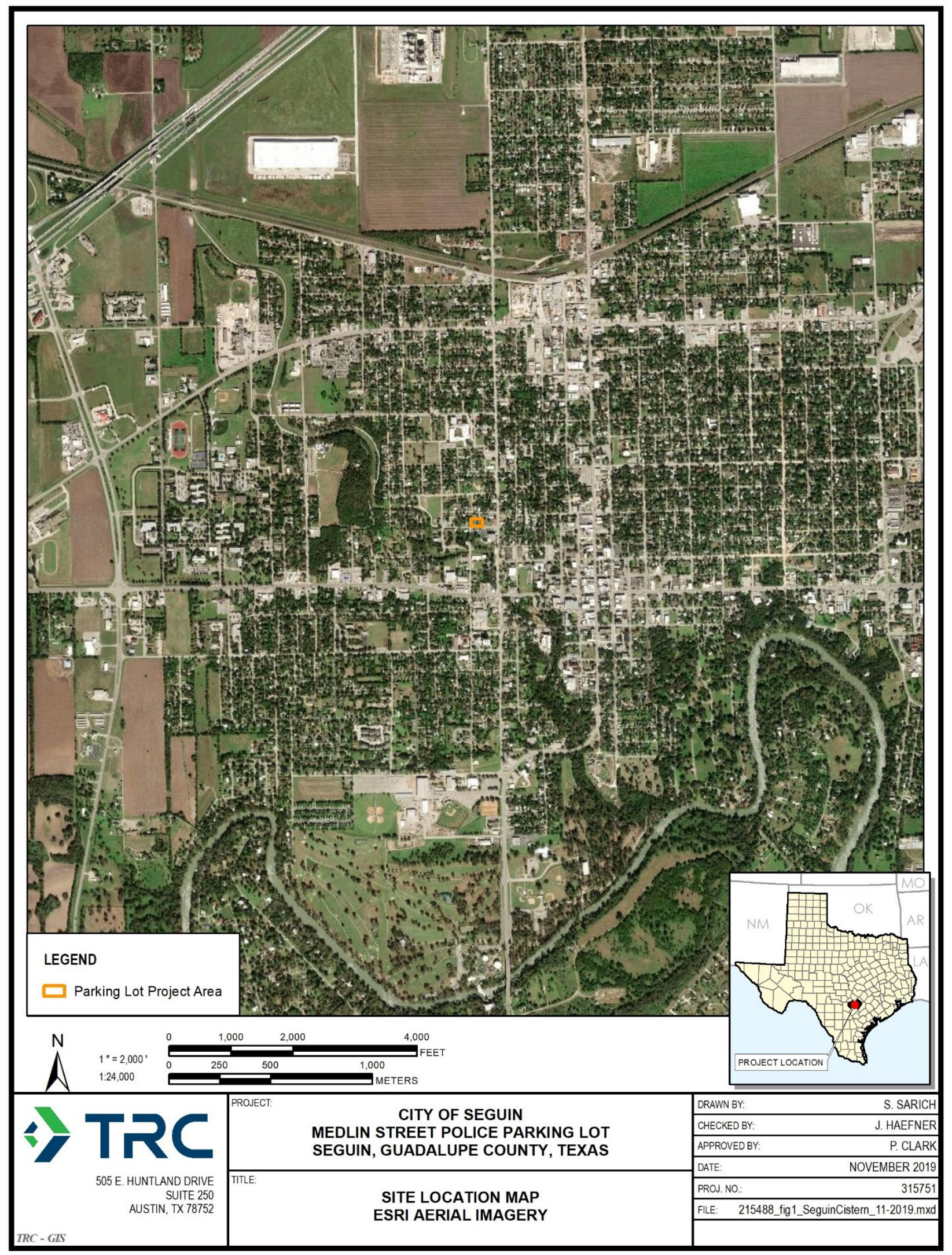

Figure 2. Parking Lot APE Location on Aerial Photograph. 


\section{0: ENVIRONMENTAL BACKGROUND}

\subsection{GEOLOGY AND SOILS}

According to the Geologic Atlas of Texas (Beaumont Sheet), the geology of the proposed project area is mapped as the Leona Formation (Qle) (Figure 3). Consisting of fluviatile terrace deposits of gravel, sand, silt, and clay, the Leona Formation dates to the Pleistocene and may correlate with Onion Creek Marl, mapped to north in Travis County. The soils within the APE are mapped as Queeny gravelly loam, with 1 to 5 percent slopes $(\mathrm{QeC})$ (Figure 4). This series consists of well drained soils that formed in calcareous loam over gravelly alluvium that originated from shale, claystone, siltstone, or chalk of Cretaceous age. This series has low geoarcheological potential at any depth below the ground surface. 


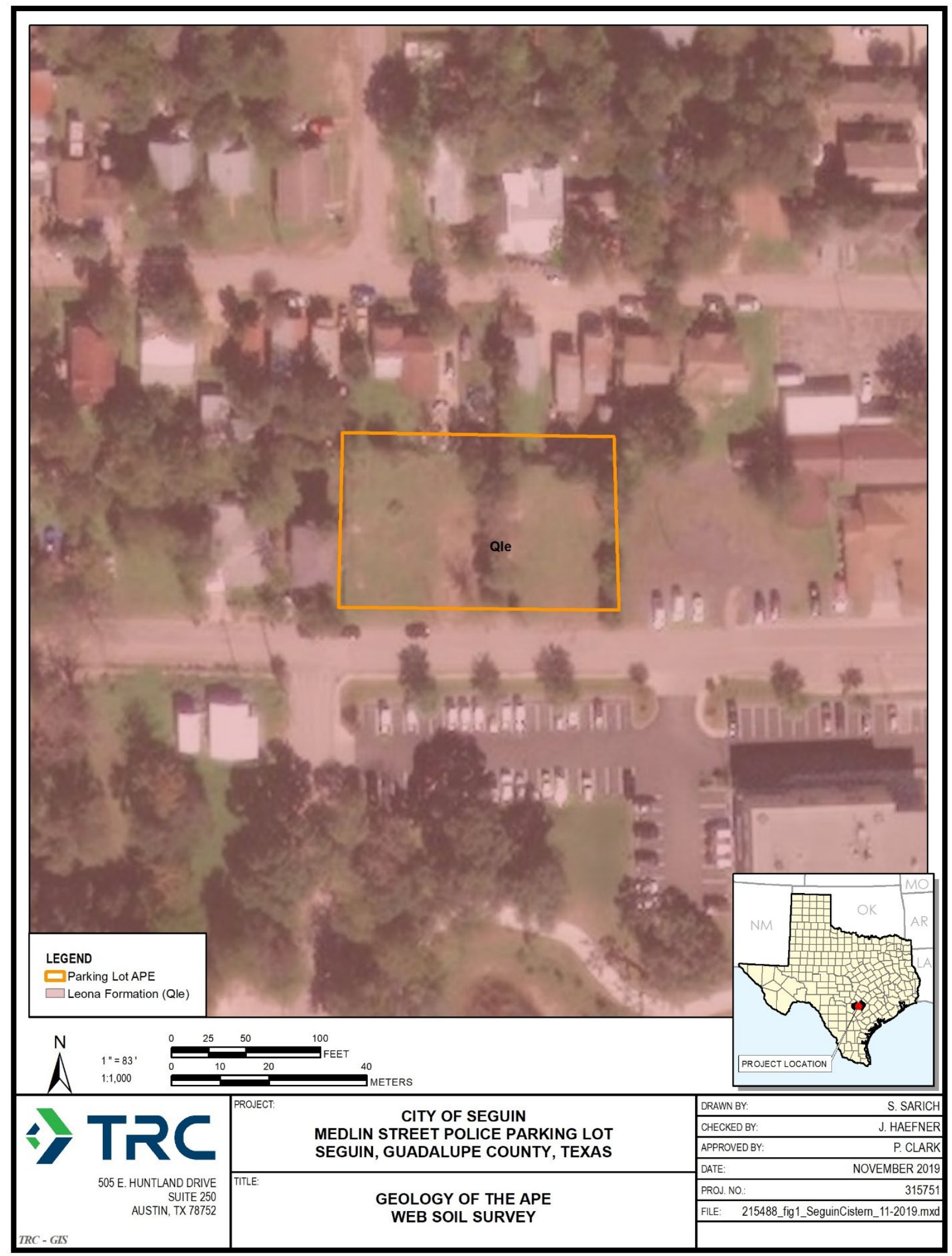

Figure 3. Geology of the APE. 


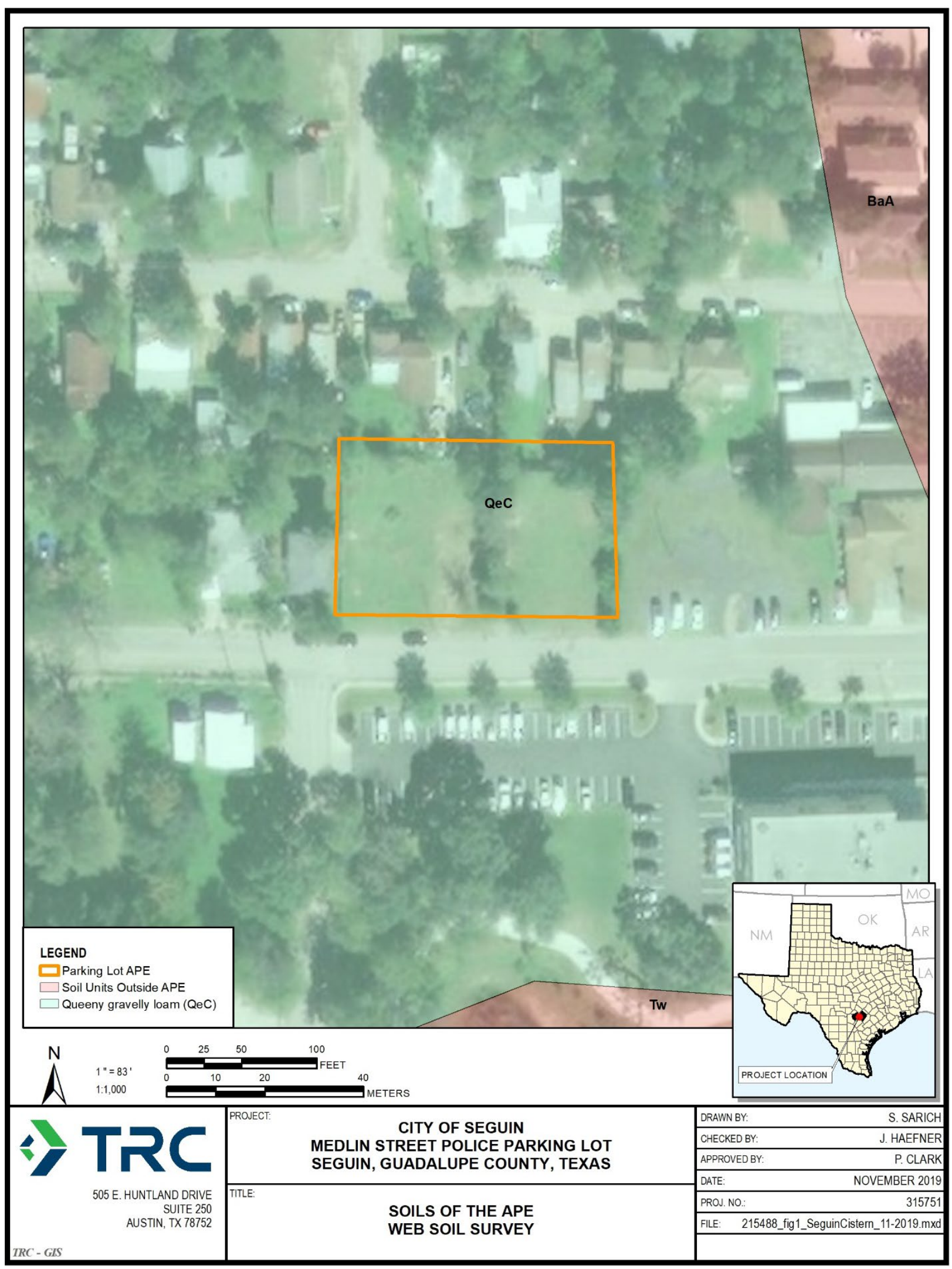

Figure 4. Soils of the APE. 
This page intentionally left blank 


\section{0: Historic CONTEXT}

\subsection{GUADALUPE COUNTY AND THE CITY OF SEGUIN (1535 TO PRESENT)}

Guadalupe County is located in South Central Texas, northeast of San Antonio and south of Austin. The first European to travel through the Seguin region was Cabeza de Vaca, who crossed the Guadalupe River at the confluence with the San Marcos River sometime between 1535 and 1536. At this time, the area was occupied by semi-sedentary Lipan Apaches and Tonkawa Indians. The area around Seguin was first recorded in 1718 by Father Francisco Celiz as part of expeditions through the area conducted by the Governor of Coahuila, Martin de Alarcon. They camped just west of Seguin. By the early 19th century, Mexicans, Europeans, and Anglos had settled the region, the closest ranch being that of Jose Antonio Navarro three miles north of Seguin. In 1831, the Humphries Branch was granted land along the Guadalupe River, and in 1833 built a cabin that is likely the first Anglo residence in what would later become the City of Seguin. In 1836, the Republic of Texas gained independence from Mexico. In 1838, Joseph F. Martin created a town site along a tributary of the Guadalupe River and named it Walnut Springs. The town was divided into four sections: farming lots, timber lots, acre lots, and central lots. In 1839, the name was changed to Seguin after Juan N. Seguin. From Gesick (2000):

Juan Seguin - Organized a Company of Mexican Patriots under Sam Houston, led the cavalry charge at San Jacinto, Mayor of San Antonio, Republic Senator, fought against Americans at the 1842 Battle of Salado, self-imposed exile in Nuevo Laredo, County Judge of Wilson County during the Reconstruction period, close friend of the Austins and many military leaders of Texas, awarded a pension by the State for his military services.

In 1842, the Congress of the Republic of Texas created Guadalupe County in response to a request by the citizens of Seguin. During the Republic of Texas period (1836-1846) there were numerous altercations with the Comanche's in the Seguin area, partly as a result of agents of the Mexican government intentionally inciting rebellion among Native American groups and Mexican populations within the Republic (Gesick 2000). The Texas Rangers provided Seguin with protection during this period, and their camp was located along Walnut Branch near Guadalupe Street. Eventually, many of these Rangers would become founding residents of Seguin (Gesick 2000).

Many of the earliest homes were built from adobe. One of the earliest is the Hall-Burges-Glenwinkel home, built in 1838 by Captain Robert Hall along Walnut Branch. Other homes, like the Campbell Log Cabin, currently located on East Live Oak Street, were built from timber. There were at least a dozen homes in Seguin by 1840. By 1845 the first school classes were being taught in an adobe building at the corner of Milam and Nolte Streets. By 1850 a high school was built from concrete on South Austin Street by Dr. John Parks and is now the Saint James Catholic School (Gesick 2000).

In 1845 the United States annexed Texas. The majority of voters approved of the annexation and the new State's constitution that sanctioned slavery and the immigration of slave owners to Texas. The 1840's and 1850's saw a wave of immigration to Texas by Germans and other Europeans, many who passed through Seguin on their way westward. This created a boom for the local economy and the period from 1845 to 1860 saw the construction of many buildings and substantial infrastructure, including a stagecoach route. By 1860 at least 100 concrete structures had been built, of which 29 are still standing (Gesick 2000). 
The residents of Seguin were pro-slavery by 1860 and two military camps had been created in Guadalupe County. In 1961 Company D, led by Captain Nathanial Benton was organized and assembled at the Seguin courthouse on June 28th. The Company would eventually travel as far east as Virginia and participate in the battles of Etham's Landing, Seven Pines, and Gaines Mill. When General Lee surrendered in 1865, 18 of the original members of Company D were present. Three residents of Seguin would become Generals in the Confederacy. The Civil War period saw a decline in the prosperity Seguin had experienced in the 1840's and 1850's. However, as skirmishes never occurred within Seguin, there was no destruction of farms or communities as experienced in other parts of the Confederacy (Gesick 2000).

In 1867 the Freedmans Bureau was created across from Market Square and Union soldiers were stationed along Live Oak Street to enforce Reconstruction laws and assist freed slaves. Public education for African American children was offered in 1871, and largely aided by Baptist and Methodist churches. By 1874, the City had partly recovered from the economic downturn created during the Civil War, and some African American families were landowners. The economic recovery was partially fueled by a shift towards cattle ranching (Gesick 2000).

In 1876, African American citizens of Seguin created the Abraham Lincoln School, which later became the Ball High School in 1925. The school was name after Reverend William Baton Ball, who was instrumental in providing education to the African American community. From 1887-1936, Guadalupe College, provided college level education for African Americans. In 1912 Texas Lutheran College was from Brenham to Seguin and was renamed Texas Lutheran University in 1996 (Gesick 2000).

The discovery of oil in the Darst Creek fields in the 1920's provided Seguin with a welcomed economic boost, and the City continued to produce notable residents. From the Handbook of Texas Online:

State Senator Ferdinand C. Weinert of Seguin was responsible for long-lasting prison reforms and also worked to establish the Pasteur Institute of Texas, which saved many lives in the treatment of rabies. Hilda Blumberg Weinert's contributions to education and politics in Texas were also important. As the twentieth century progressed Seguin attracted manufacturing and service-oriented industries to diversify its agricultural and oil-based economy. In 1986 the Seguin city government changed from the mayor-council form of city government to the council-manager form of city government. By 1988 the town had an estimated population of 22,000 and more than thirty businesses that employed more than fifteen full-time workers each. By that year also the county hospital had expanded to seventy-five beds. The Seguin-Guadalupe County Library continued its expansion to more than 50,000 volumes, and the Seguin Gazette-Enterprise celebrated its centenary year in 1988. On August 12, 1988, Seguin celebrated its sesquicentennial year. Tourists were attracted to Max Starcke Park, the Guadalupe County Coliseum, and the County Fairgrounds, where the Texas State High School Rodeo has been held since 1984. The town boasted a number of antebellum homes, including the Sebastopol House State Historic Structure, and the greater Seguin area was the setting for author Janice Woods Windle's successful novel True Women (1993), featured in a television miniseries in 1997. In 2000 Seguin had a population of 22,011 and 1,338 businesses. 


\section{0: RESEARCH \& METHODS}

\subsection{RESEARCH AND METHODS}

TRC archaeologists conducted a limited desktop literature and archives review prior to survey of the APE in November 2019 to determine whether previously recorded cultural resources have been documented within the APE, immediately adjacent to the APE, or within a one-mile (1.6-km) radius of the APE. This review included utilization of THC-Atlas, historic United States Geological Survey (USGS) 7.5-minute topographic quadrangles, and Google Earth imagery. These sources provided information regarding the location of previously conducted archeological surveys, recorded archeological sites, cemeteries, properties currently listed or eligible for listing on the National Register of Historic Places (NRHP), Recorded Texas Historic Landmarks (RTHLs), and SALs..

On November 13, 2019, TRC archeologists Josh Haefner and Steven Sarich conducted survey of the APE including documentation of the inadvertent discovery identified as a potentially historic cistern. Once the location of the cistern was determined, the overlying gravel aggregate was carefully cleared away from the cistern opening and the inadvertent discovery/cistern documented. The location and results of the visual survey were recorded with an electronic form created by TRC with Fulcrum, a mobile form builder and data collection app. The Fulcrum application runs on Android or iOS operating systems and allows users to upload their data in real time (http://www.fulcrumapp.com/). Information recorded using the Fulcrum application includes feature type, modern land use, vegetation, average ground surface visibility, disturbance type(s), degree of disturbance, a written feature description, feature measurements, feature photographs, and general project overview photographs. Additionally, the single grave marker located in the northwest corner of the APE that was identified prior to construction was documented and digitally recorded to ensure that the parking lot construction had not impacted the burial and that it had been properly avoided.

Subsequent to the field survey, TRC cultural personnel conducted additional archival and historic sources research related to the tract of land on which the inadvertent discovery/cistern and grave marker are located. The purpose of this research was to provide additional context to the cistern and grave marker that will inform the subsequent recommendation(s) made by TRC cultural personnel. Archival and historic sources that were reviewed include property deed records at the Guadalupe County Clerk's Office and family histories and genealogical information courtesy of the Seguin Public Library and historical topographic maps dating to 1911 (San Marcos 1:125,000), 1919 (San Marcos 1:125,000), 1924 (San Marcos 1:48,000), 1930 (Seguin 1:62,500), and 1953 (Seguin 1:62,500). 
This page intentionally left blank 


\section{0: ReSUlts}

\subsection{CURRENT APE CONDITIONS AND RESULTS}

The asphalt parking lot is located at the northeast corner of the intersection of Medlin Street and North Saunders Street in downtown Seguin, Texas and will be approximately 0.50 acres in size (Appendix A). The surrounding area is largely urban development with residences located to the north, east, and west. The Seguin City Police department is located south of the APE and south of Medlin Street. No above-ground historic resources were documented on the THC-Atlas and none were noted within the APE during the visual survey. During the field visit on November 13, 2019 it was noted that any standing structure(s) had already been razed and grading of the parking lot location had already occurred (Figure 5). As a result no subsurface excavations were conducted.

The inadvertent discovery/cistern (41GU211) is located 30 meters (m) [98 feet (ft)] north of Medlin Street

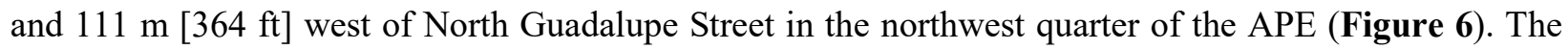
brick-lined cistern has a cast iron circular grate over top, possibly an old iron spoke wheel. The cistern opening measures approximately 92 centimeters (cm) [36 inches (in)] in diameter and is 15 to $20 \mathrm{~cm}$ [6 to 8 in] below grade (Figure 7). The bricks appear to be cut limestone and measure approximately $13 \mathrm{~cm}$ [5 in] long by $6 \mathrm{~cm}$ [2 in] wide on average (Figure 8). The cone-shaped, brick lined neck measures approximately $155 \mathrm{~cm}$ [61 in] deep before giving way to natural cut geology. The overall depth of the cistern is approximately $3 \mathrm{~m}$ [10 ft] however large amounts of gravel have dropped into and accumulated at the bottom (Figure 9). A ceramic drainage pipe is visible in the south wall and measures approximately 10 to $12 \mathrm{~cm}$ [4 to $5 \mathrm{in}$ ] in diameter (Figure 10). A small number of red brick fragments surround the cistern opening. These are likely from the residence that was razed prior to initial parking lot construction (Figures 11 and 12).

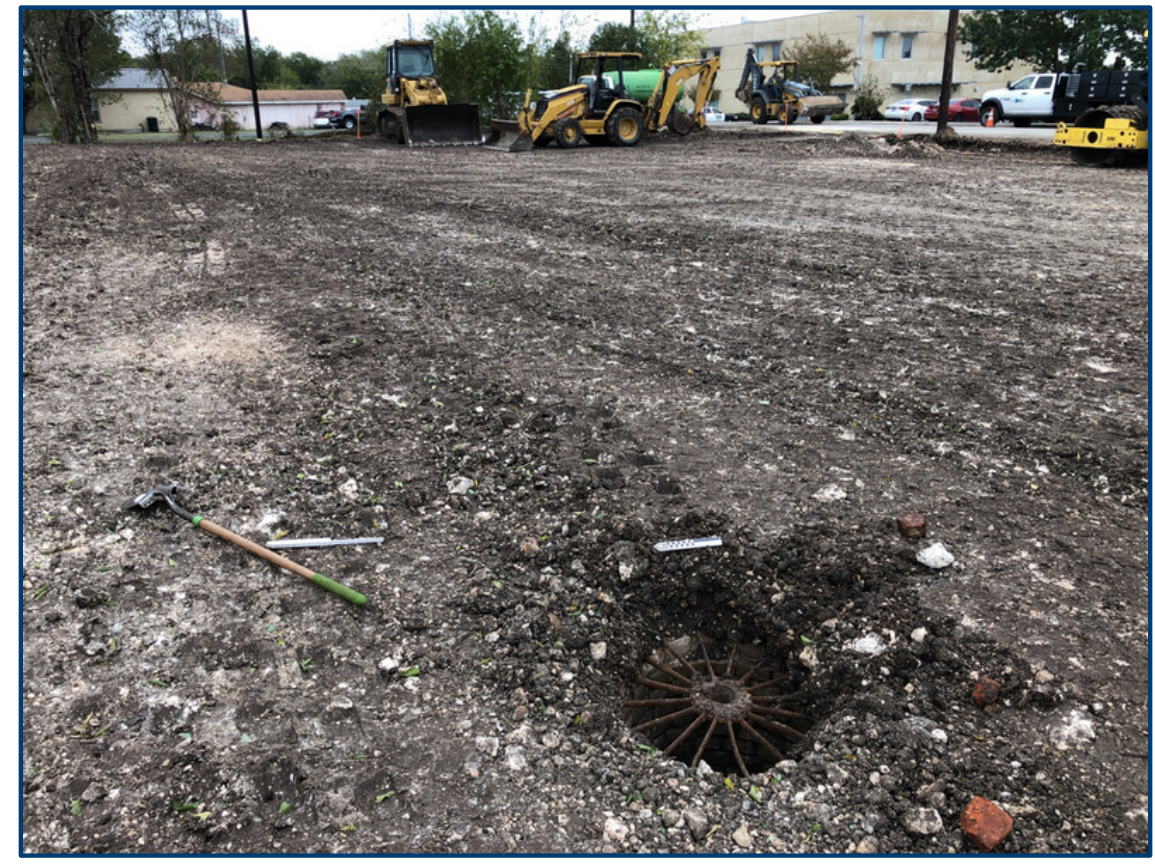

Figure 5. Overview of Parking Lot Location and Existing Construction Activities, Facing South. 
Figure 6. Figure Redacted Due to Sensitive Site Data. 


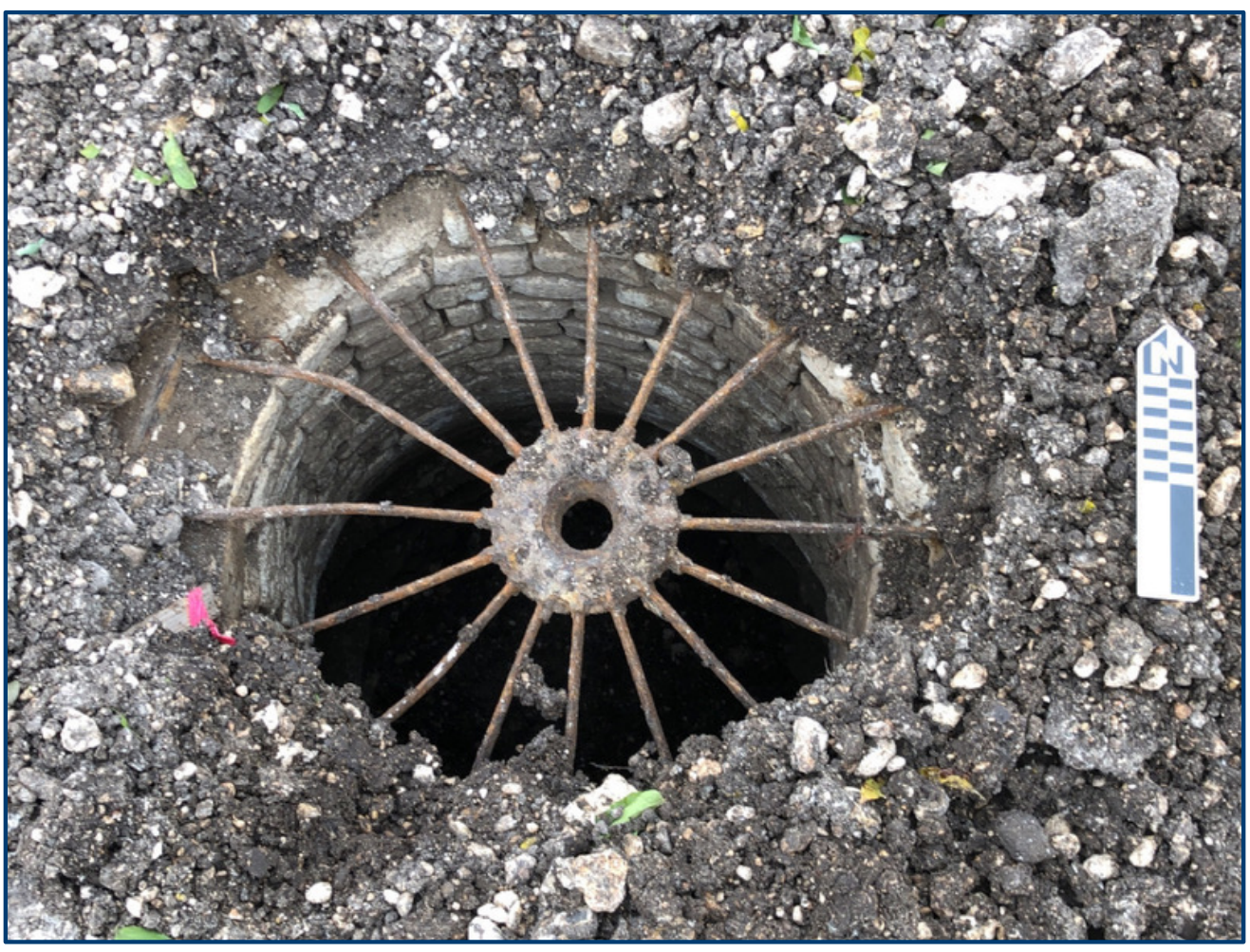

Figure 7. Cistern Opening, Facing North.

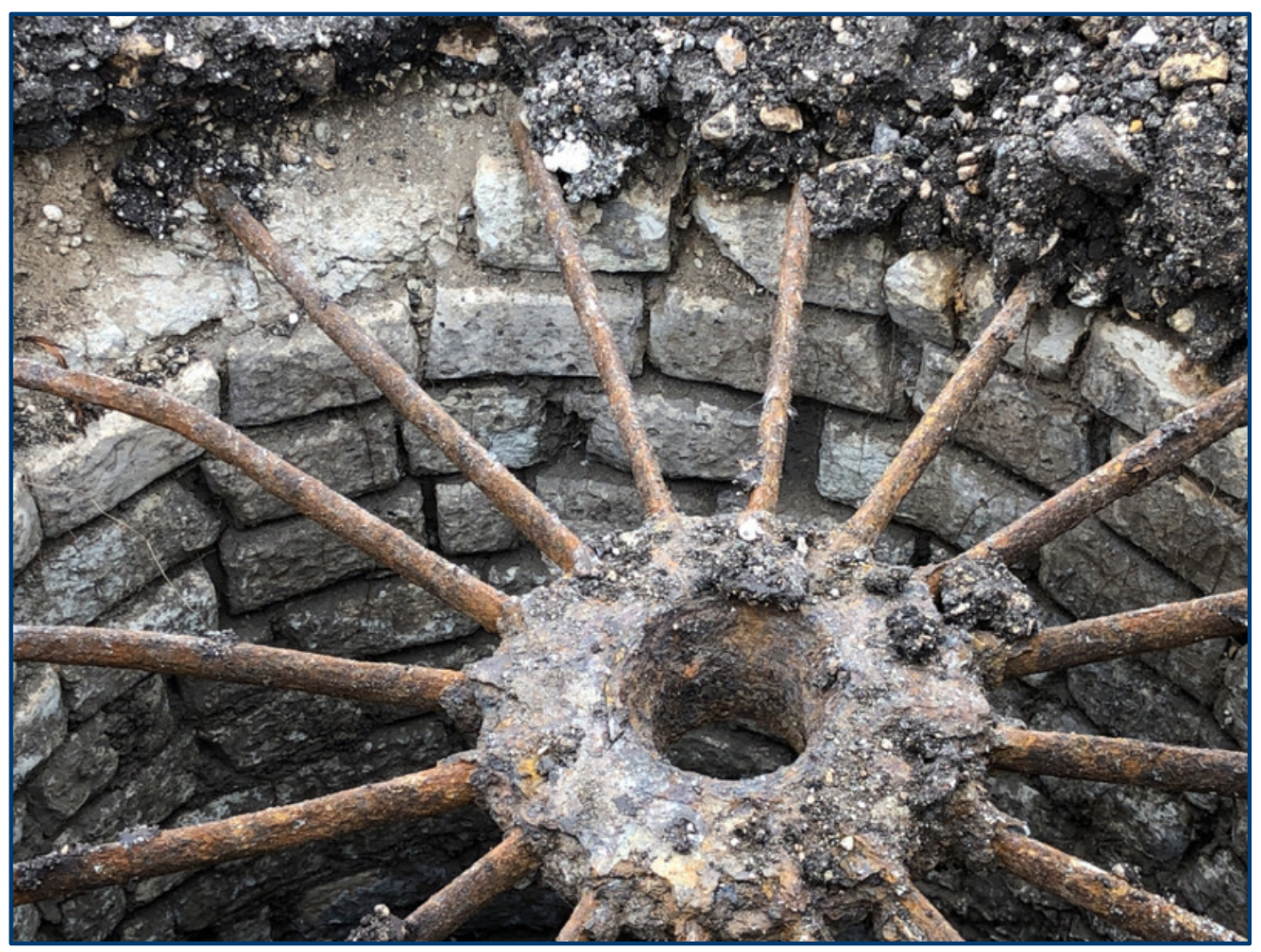

Figure 8. Cut Limestone Brick Lining Cistern, Facing North. 


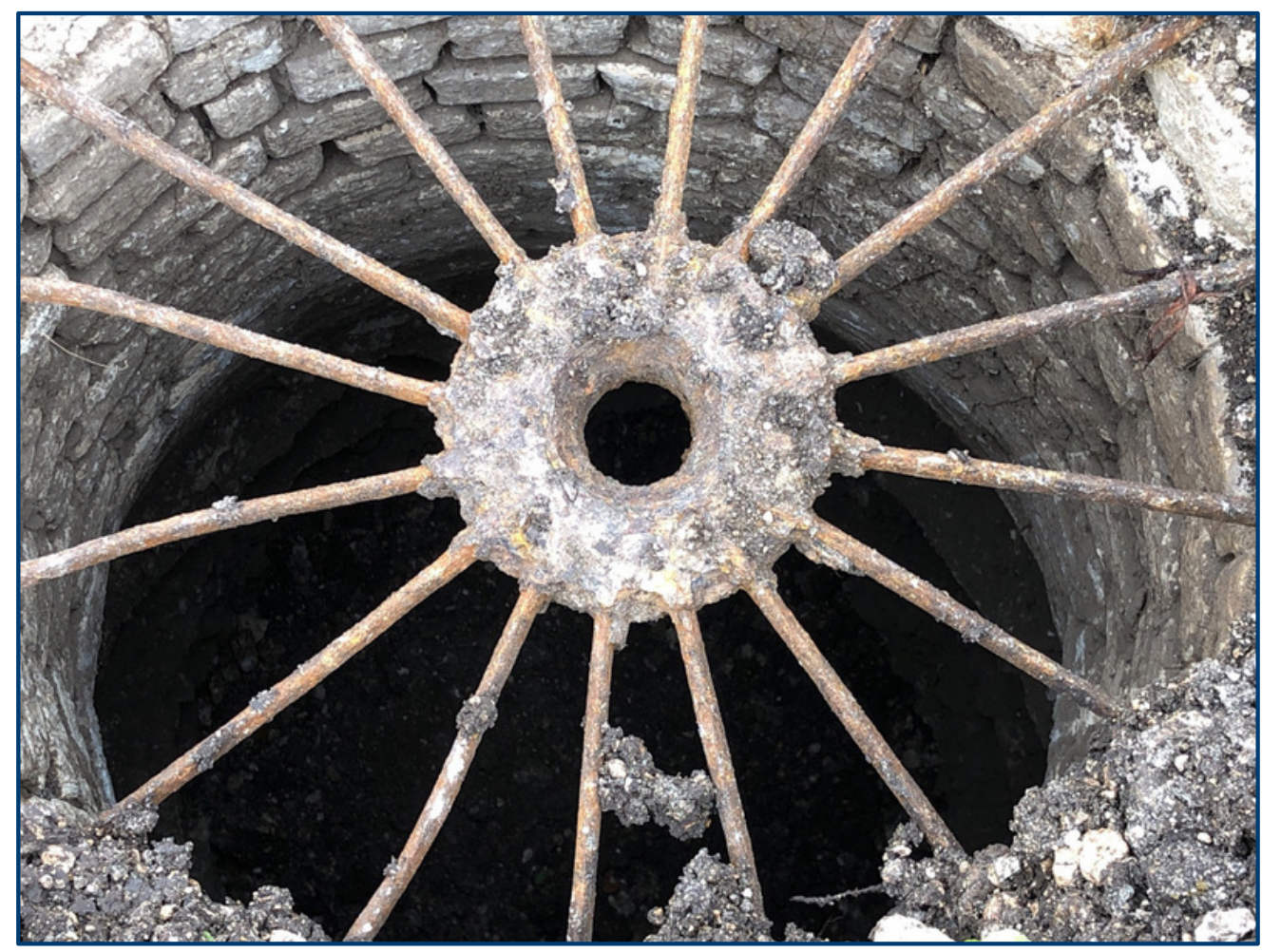

Figure 9. Cistern Interior with Accumulated Gravel at the Bottom, Facing North.

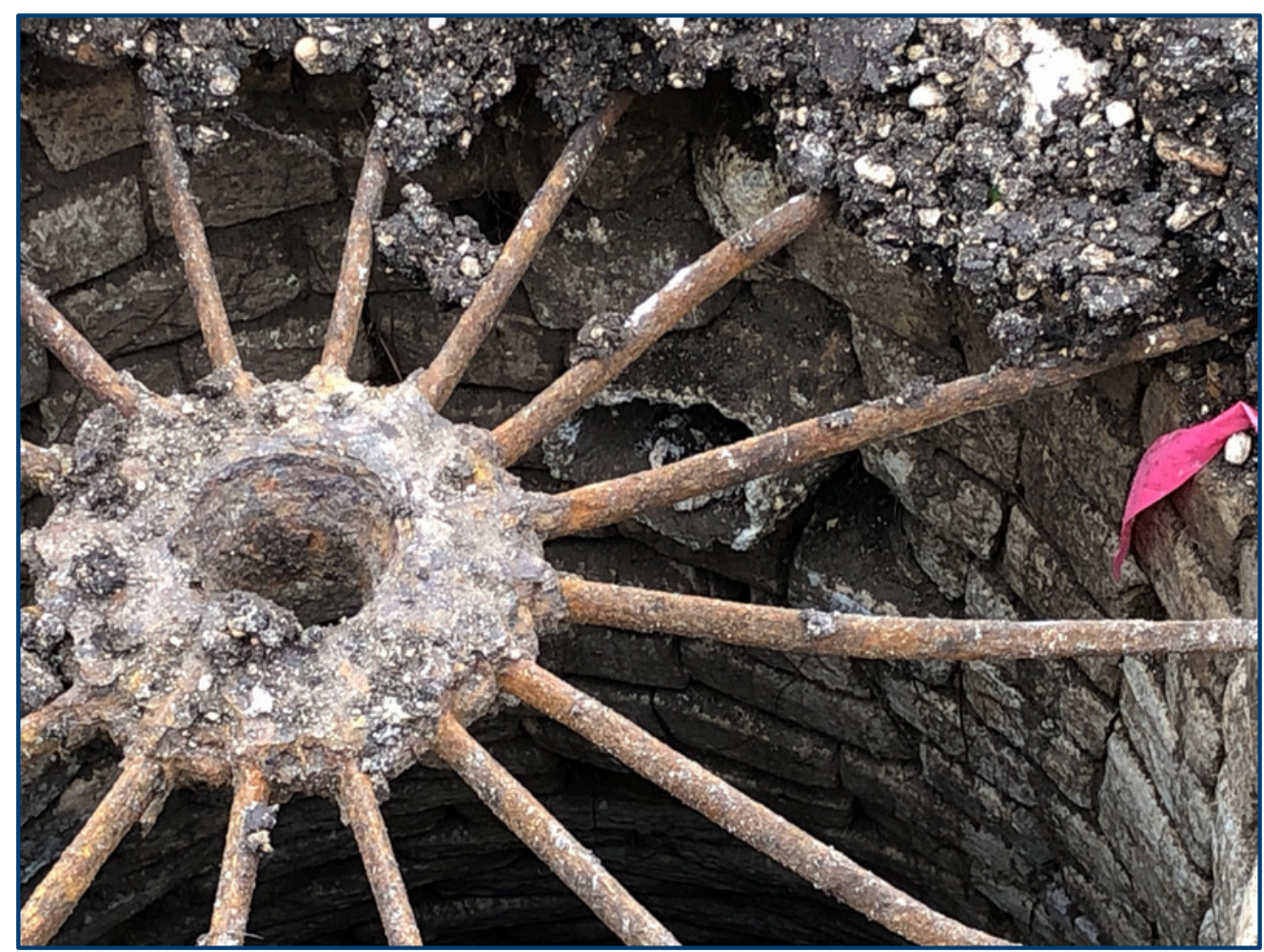

Figure 10. Ceramic Drainage Pipe in South Wall, Facing South. 


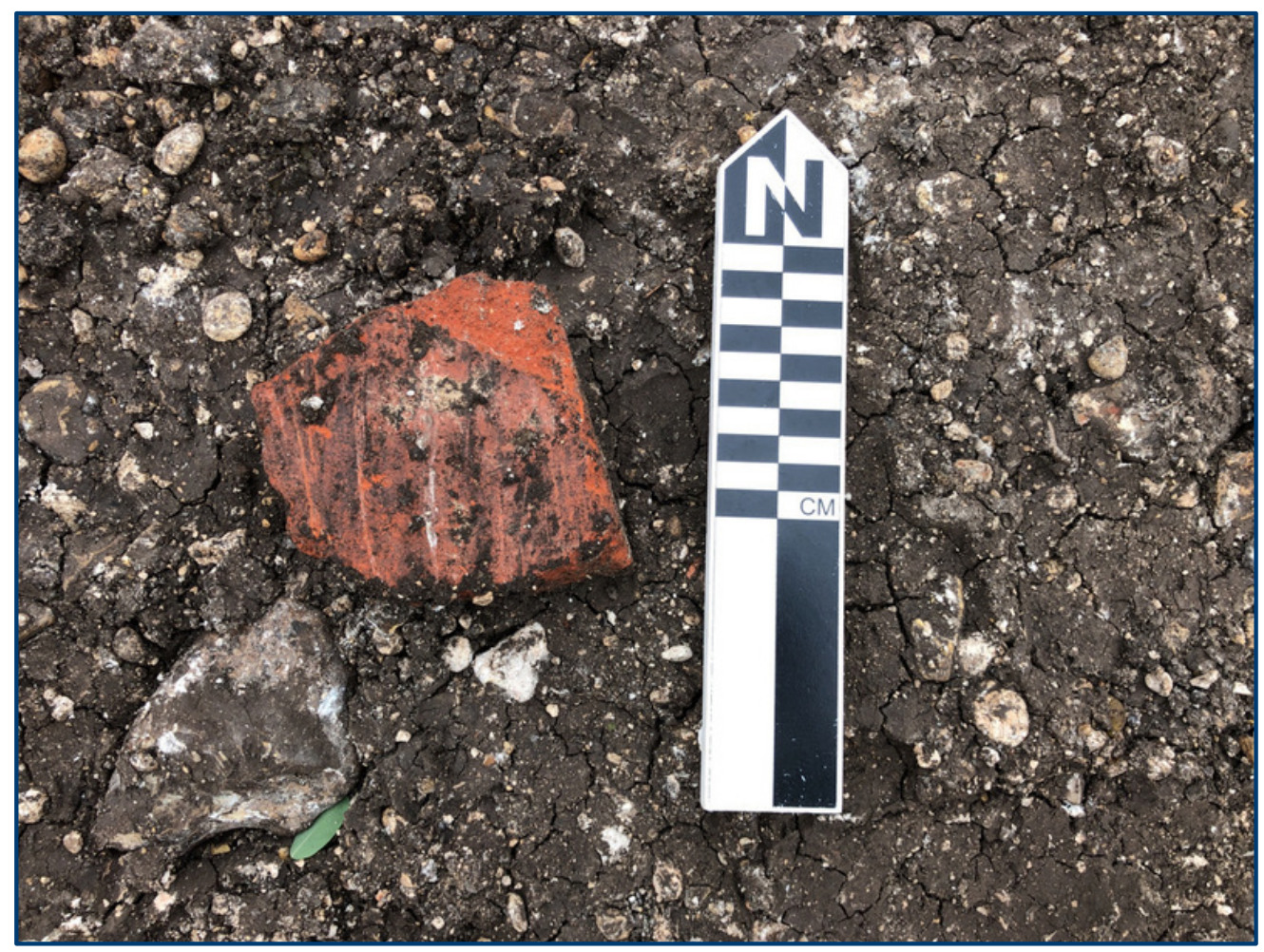

Figure 11. Red Brick Fragment West of Cistern Opening, Facing North.

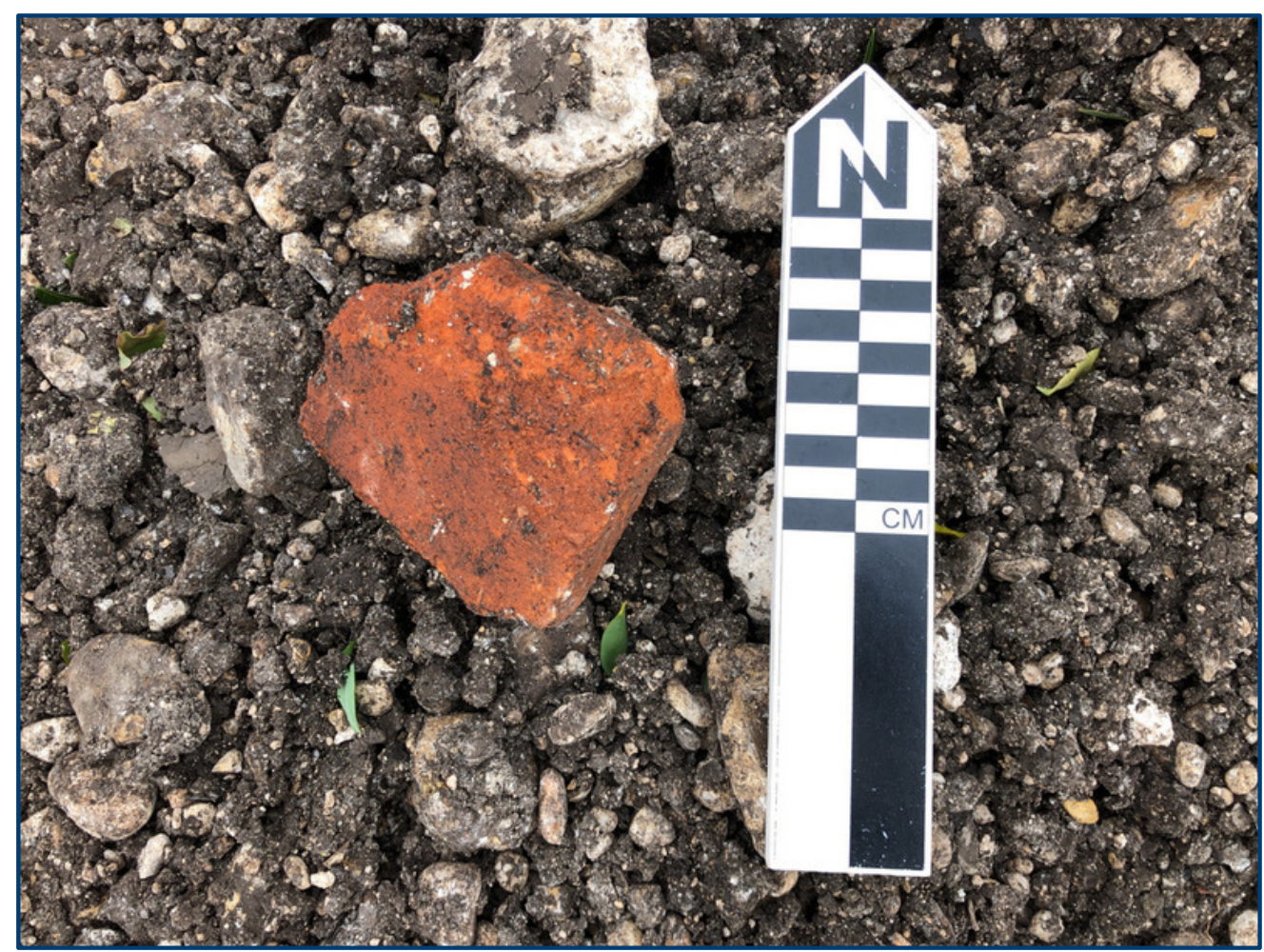

Figure 12. Red Brick Fragment East of Cistern Opening, Facing North. 
Subsequent to the documentation of the brick lined cistern, the single grave marker located in the northwest corner of the APE was inspected to determine if there were any impacts from the construction activities (See Figure 6). The only evidence of the grave location was a flat, unmarked concrete slab adjacent to two intersecting fence lines surrounding residences to the north and west. Additional construction fencing had been placed around the perimeter of the grave location as well. All construction activities avoided the grave location and no impacts were noted (Figures 13 and 14).

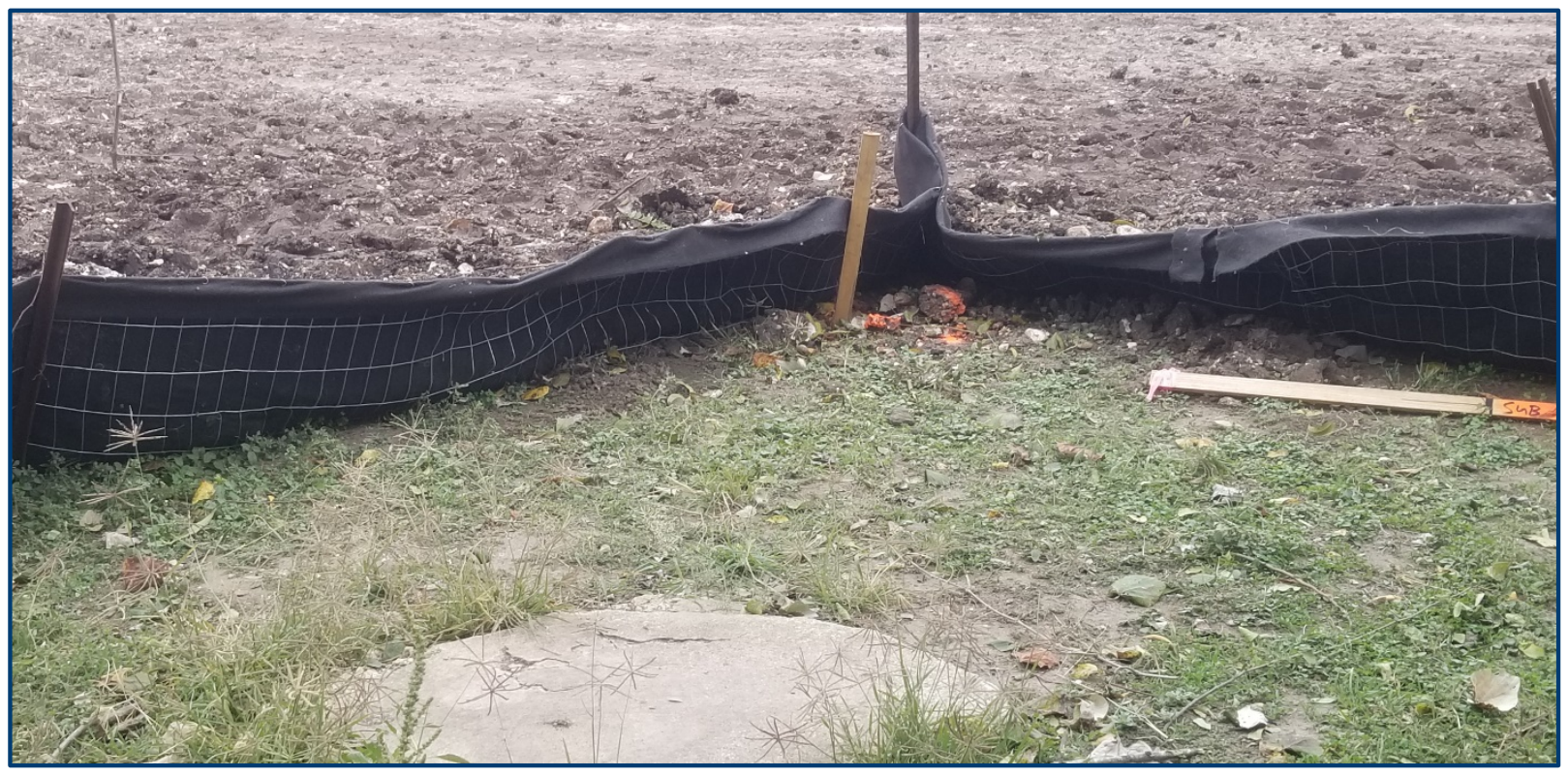

Figure 13. Overview of Single Grave Marker Location with Construction Fencing, Facing Southeast.

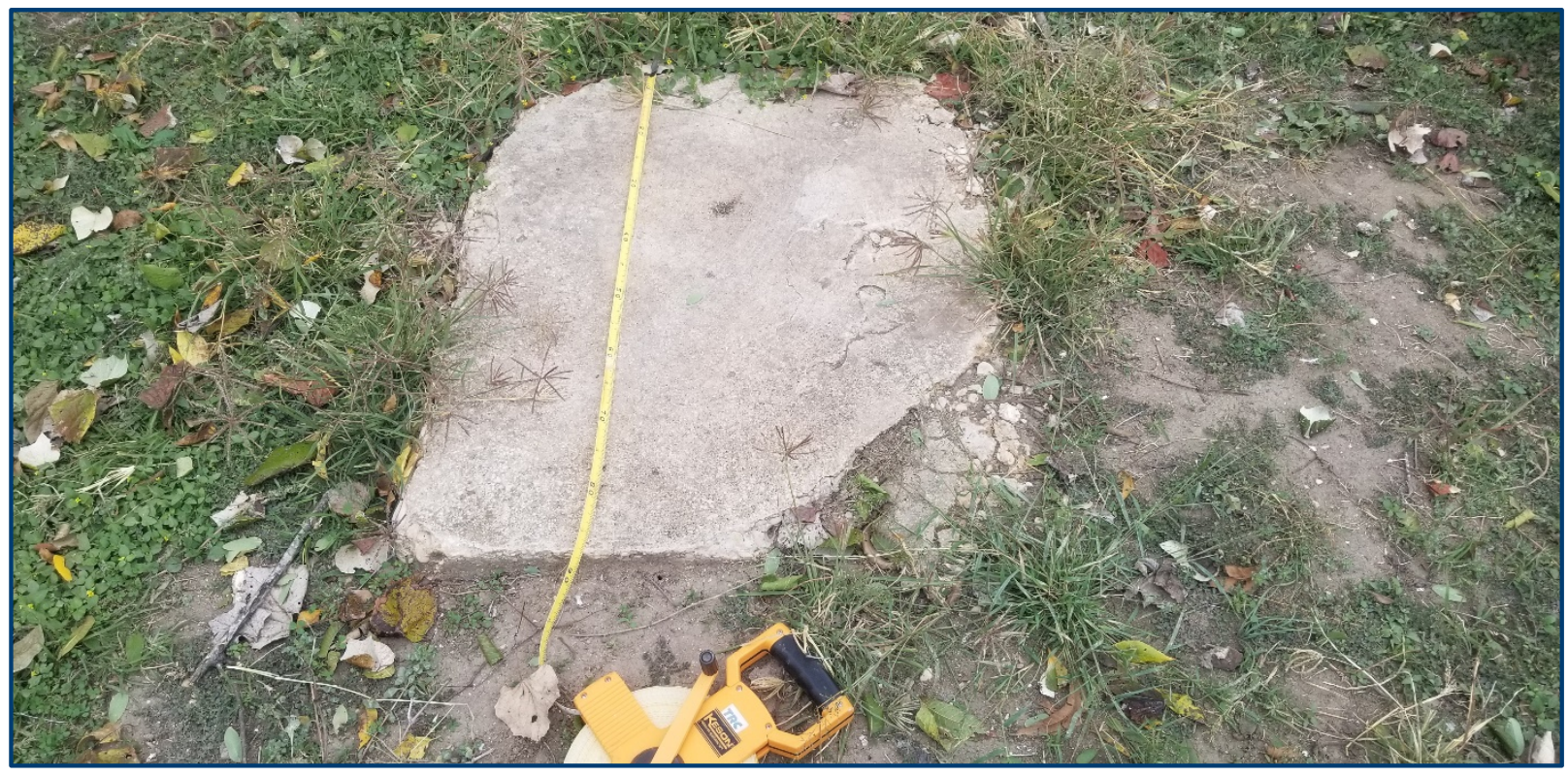

Figure 14. Closeup of Single Grave Marker, Facing North. 


\section{0: ARChival AND Historic BaCKGROUnd ReSEARCH RESULTS}

\subsection{CULTURAL RESOURCES FILE SEARCH}

According to the THC-Atlas, no cultural resources are recorded within the APE nor has this area been surveyed, though 14 previous archaeological investigations have been conducted within one mile of the APE (Table 1). Ten previously recorded archaeological sites, four cemeteries, and one the Seguin Commercial Historic District are located within one mile of the APE (Figure 15, Table 2). The THC-Atlas lists 17 markers as being located within one mile of the APE: Humphrey House, Sonka House, Women's Club Rooms, Colonel Benton, Black Education in Seguin, Juan Seguin, Sebastopol, Guadalupe County, Saint Andrew's Episcopal Church, Hugo and Georgia Gibson House, Guadalupe High School, Los Nogales, Moore House, John F. McGuffin, Samuel Millett, Riverside Cemetery, and Colonel Ireland.

Table 1. Previously Conducted Archeological Surveys Within a 1-Mile Radius of the APE.

\begin{tabular}{|c|c|c|c|}
\hline $\begin{array}{l}\text { Archeological Survey } \\
\text { Atlas No. }\end{array}$ & $\begin{array}{l}\text { Type of Cultural } \\
\text { Resource Survey }\end{array}$ & Archeological Survey Description & $\begin{array}{l}\text { TAC Permit } \\
\text { No }\end{array}$ \\
\hline 8500002572 & $\begin{array}{l}\text { Archaeological } \\
\text { Area (Survey) }\end{array}$ & Phase I Survey was conducted in 1988 by USACE & Not Available \\
\hline 8500076633 & $\begin{array}{l}\text { Archaeological } \\
\text { Area (Survey) }\end{array}$ & Phase I Survey was conducted in 2015 by TRC & 7301 \\
\hline 8500048594 & $\begin{array}{l}\text { Archaeological } \\
\text { Linear (Survey) }\end{array}$ & $\begin{array}{l}\text { Survey was conducted for the Walnut Branch Hike and Bike Survey in } 2013 \text { by HRA Gray and Pape for } \\
\text { TxDOT. No archaeological sites were recorded. No additional information was available in THC-Atlas. }\end{array}$ & 6464 \\
\hline 8500029747 & $\begin{array}{l}\text { Archaeological } \\
\text { Area (Survey) }\end{array}$ & $\begin{array}{l}\text { Jacobs conducted a survey in } 2013 \text { for USACE - Fort Worth District and the City of Seguin for the Walnut } \\
\text { Branch Restoration Project. No Archaeological sites were encountered. No further information was available } \\
\text { in THC-Atlas. }\end{array}$ & 6110 \\
\hline 8500000280 & $\begin{array}{l}\text { Archaeological } \\
\text { Data Recovery }\end{array}$ & $\begin{array}{l}\text { A data recovery project was conducted in } 1988 \text { for Texas Parks and Wildlife. No additional information was } \\
\text { available in the THC-Atlas, however, site } 41 \mathrm{GU} 9 \text { is located within the survey area. }\end{array}$ & Not Available \\
\hline 8500077412 & $\begin{array}{l}\text { Archaeological } \\
\text { Area (Survey) }\end{array}$ & $\begin{array}{l}\text { Phase I Survey was conducted in } 2015 \text { by TRC on behalf of the City of Seguin and the USACE. This project } \\
\text { resulted in the inadvertent discovery of a }\end{array}$ & 7251 \\
\hline 8500000098 & $\begin{array}{l}\text { Archaeological } \\
\text { Area (Survey) }\end{array}$ & In 1997, TPWD conducting archeological survey at Riverview Park. & Not Available \\
\hline 8500025347 & $\begin{array}{l}\text { Archaeological } \\
\text { Area (Survey) }\end{array}$ & $\begin{array}{l}\text { In 2012, an archeological survey was conducted along portions of Segment G for the proposed State Highway } \\
\text { (SH) } 99 \text { project (Grand Parkway) in Harris County and Montgomery Counties, Texas for the Texas Department } \\
\text { of Transportation. }\end{array}$ & 6102 \\
\hline 8500032548 & $\begin{array}{l}\text { Archaeological } \\
\text { Area (Survey) }\end{array}$ & Phase I Survey was conducted in 2013 by SWCA & 6489 \\
\hline 8500016312 & $\begin{array}{l}\text { Archaeological } \\
\text { Area (Survey) }\end{array}$ & Phase I Survey was conducted in 2009 by PBS \& J & 5311 \\
\hline 8500011764 & $\begin{array}{l}\text { Archaeological } \\
\text { Area (Survey) }\end{array}$ & Phase I Survey was conducted in 2004 by PBS \& J & 2769 \\
\hline 8500029746 & $\begin{array}{l}\text { Phase II } \\
\text { Archaeological } \\
\text { Survey }\end{array}$ & Phase II Survey was conducted in 2004 by AmaTerra & 6162 \\
\hline 8500053831 & $\begin{array}{l}\text { Archaeological } \\
\text { Area (Survey) }\end{array}$ & Phase I Survey was conducted in 2013 by Gray \& Pape, LLC & 6536 \\
\hline 8500011524 & $\begin{array}{l}\text { Archaeological } \\
\text { Area (Survey) }\end{array}$ & Phase I Survey was conducted in 2004 by SWCA & Unknown \\
\hline
\end{tabular}


Figure 15. Figure Redacted Due to Sensitive Site Data. 
Table 2. Previously Recorded Cultural Resources Within a 1-Mile Radius of the APE

\begin{tabular}{|c|c|c|}
\hline $\begin{array}{l}\text { Type of Cultural } \\
\text { Resource }\end{array}$ & Description & $\begin{array}{l}\text { NRHP } \\
\text { Eligibility or } \\
\text { Significance }\end{array}$ \\
\hline Archaeological Site $41 \mathrm{GU} 7$ & $\begin{array}{l}\text { Secondary deposition of a light scatter of debitage and burned rock located on } \\
\text { a moderately sloping hillside near crest of hill recorded in } 1975 \text { noted to be in } \\
\text { poor condition }\end{array}$ & $\begin{array}{l}\text { Undetermined NRHP } \\
\text { eligibility }\end{array}$ \\
\hline Archaeological Site 41 GU9 & $\begin{array}{l}41 \text { GU9 is the trinomial assigned to the Sebastol State Historic Structure and } \\
\text { associated property }\end{array}$ & $\begin{array}{l}\text { Designated as an SAL in } \\
1983\end{array}$ \\
\hline $\begin{array}{l}\text { Archaeological Site } \\
41 \mathrm{GU} 16\end{array}$ & $\begin{array}{l}\text { The Atlas notes this as the oldest house in Seguin, constructed of sun dried } \\
\text { brick. By } 1765 \text { it was a station stop on Old Spanish Trail. }\end{array}$ & $\begin{array}{l}\text { Undetermined NRHP } \\
\text { eligibility }\end{array}$ \\
\hline $\begin{array}{l}\text { Archaeological Site } \\
41 \mathrm{GU} 30\end{array}$ & $\begin{array}{l}\text { Site is a subsurface prehistoric occupation area with deposits dating to the } \\
\text { Early Archaic and Late Prehistoric. During its relocation in } 1986 \text { it was noted } \\
\text { that the site was being destroyed by development. }\end{array}$ & $\begin{array}{l}\text { Undetermined NRHP } \\
\text { eligibility }\end{array}$ \\
\hline $\begin{array}{l}\text { Archaeological Site } \\
41 \mathrm{GU} 113\end{array}$ & $\begin{array}{l}\text { Historic Period trash dump from the early } \\
\text { 20th century. }\end{array}$ & $\begin{array}{l}\text { Determined Ineligible in } \\
\text { ROW by THC/SHPO in } \\
2009\end{array}$ \\
\hline $\begin{array}{l}\text { Archaeological Site } \\
41 \mathrm{GU} 114\end{array}$ & $\begin{array}{l}\text { Site is a multi-component site consisting of historic ceramics, metal, and } \\
\text { glass, and a minimal amount prehistoric material. }\end{array}$ & $\begin{array}{l}\text { Determined Ineligible in } \\
\text { ROW by THC/SHPO in } \\
2009\end{array}$ \\
\hline $\begin{array}{l}\text { Archaeological Site } \\
41 \mathrm{GU} 115\end{array}$ & $\begin{array}{l}\text { Site consists of historic material and a small amount of burned rock It appears } \\
\text { the deposit is from household trash dumping that dates to the early 20th } \\
\text { century. Artifacts present included historic ceramics, glass, metal, burned } \\
\text { rock, a button, and faunal bone. The site is possibly the result of trash } \\
\text { dumping during the early 20th century from a nearby residence. The deposits } \\
\text { are not well defined and appear to be in a mixed context. }\end{array}$ & $\begin{array}{l}\text { Undetermined NRHP } \\
\text { Eligibility }\end{array}$ \\
\hline $\begin{array}{l}\text { Archaeological Site } \\
41 \mathrm{GU} 159\end{array}$ & $\begin{array}{l}\text { This jail was previously located on the Guadalupe County Poor Farm. It was } \\
\text { donated to the Seguin Conservation Society on January 31, } 1986 \text { by Harriet } \\
\text { and Dick Phillips in memory of her parents Arthur and Una Schmidt, who } \\
\text { bought the property from the county, made it their homestead, and used the } \\
\text { acreage for cattle raising. }\end{array}$ & $\begin{array}{l}\text { Determined Ineligible by } \\
\text { THC/SHPO in April and } \\
\text { July of } 2009\end{array}$ \\
\hline $\begin{array}{l}\text { Archaeological Site } \\
41 \mathrm{GU} 166\end{array}$ & $\begin{array}{l}\text { This site is a prehistoric campsite consisting of a debitage scatter and bifacial } \\
\text { tools. During its recordation in } 2008 \text {, this site was noted as being highly } \\
\text { disturbed by plowing and erosion. }\end{array}$ & $\begin{array}{l}\text { Undetermined NRHP } \\
\text { Eligibility }\end{array}$ \\
\hline $\begin{array}{l}\text { Archaeological Site } \\
41 \mathrm{GU} 174\end{array}$ & $\begin{array}{l}\text { This site consists of a historic house structure (constructed in 1851) with } \\
\text { associated early to mid-twentieth century architectural features, including } \\
\text { patios, well, outbuilding foundation, sidewalk, possible linear foundation, } \\
\text { propane tank, and two gate pillars. }\end{array}$ & $\begin{array}{l}\text { Undetermined NRHP } \\
\text { Eligibility }\end{array}$ \\
\hline $\begin{array}{l}\text { Archaeological Site } \\
41 \mathrm{GU} 175\end{array}$ & This site is a late nineteenth to early twentieth century culvert & $\begin{array}{l}\text { Undetermined NRHP } \\
\text { Eligibility }\end{array}$ \\
\hline Juan Seguin Burial Site & This is the location of the Juan Seguin grave. & $\mathrm{N} / \mathrm{A}$ \\
\hline Vaughn Cemetery & $\begin{array}{l}\text { This Cemetery is located On Prexy Drive in Seguin near Texas Lutheran } \\
\text { College. North of Mill Ave (90a). }\end{array}$ & $\begin{array}{l}\text { On Prexy Drive near } \\
\text { Texas Lutheran College, } \\
\text { north of Mill Avenue. }\end{array}$ \\
\hline Saint James Cemetery \#1 & $\begin{array}{l}\text { Spring Hill Peaceful Cemetery (Spring Cemetery), located at } 26206 \text { Aldine } \\
\text { Westfield Road in Harris County, Texas has } 71 \text { interments, with the oldest } \\
\text { grave dating to } 1895\end{array}$ & $\begin{array}{l}\text { Located next to church } \\
\text { between Campbell and } \\
\text { Veterans Streets. }\end{array}$ \\
\hline $\begin{array}{l}\text { Riverview/Riverside } \\
\text { Cemetery }\end{array}$ & $\begin{array}{l}\text { This cemetery traces its origin to the Smith family graveyard established by } \\
\text { early settlers to this area in } 1880 \text {, French Smith deeded the family cemetery to } \\
\text { the City of Seguin. }\end{array}$ & $\mathrm{N} / \mathrm{A}$ \\
\hline $\begin{array}{l}\text { NRHP Property: Robert } \\
\text { Hall House }\end{array}$ & $\begin{array}{l}\text { (214 S. Travis Street) } \\
\text { The Robert Hall House is one of Seguin's most important historical } \\
\text { landmarks. The original log portion of the house was built by one of the } \\
\text { town's founders, Captain Robert Hall, an early Texas pioneer and patriot, and } \\
\text { remains the oldest house built after the city was established. }\end{array}$ & $\begin{array}{l}\text { Listed NRHP Eligible } \\
\text { Property }\end{array}$ \\
\hline $\begin{array}{l}\text { NRHP Property: Park } \\
\text { Hotel }\end{array}$ & $\begin{array}{l}\text { (217 S. River Street) } \\
\text { The Park Hotel, presently known as the Plaza Hotel, is located on lots } 1 \text { and } 2 \\
\text { and the south two-thirds of lot } 10 \text { in Inner Block 25, New City Block } 163 \text { on } \\
\text { the east side of the Courthouse square which is also known as Central Park. }\end{array}$ & $\begin{array}{l}\text { Listed NRHP Eligible } \\
\text { Property }\end{array}$ \\
\hline $\begin{array}{l}\text { NRHP Property: } \\
\text { Sebastopol House }\end{array}$ & $\begin{array}{l}\text { (Northeast Corner of West Court and North Erkel) } \\
\text { Sebastopol, located in Seguin, Texas, was the idea of a Colonel J. W. Young. } \\
\text { It is an unusual flat-roofed Greek Revival residence and demonstrates an } \\
\text { early use of poured concrete. The main level is T-shaped with inset galleries } \\
\text { along the stem of the T which support a large square water reservoir on the } \\
\text { roof. . }\end{array}$ & $\begin{array}{l}\text { Listed NRHP Eligible } \\
\text { Property }\end{array}$ \\
\hline
\end{tabular}




\begin{tabular}{|c|c|c|}
\hline $\begin{array}{c}\text { Type of Cultural } \\
\text { Resource }\end{array}$ & Description & $\begin{array}{l}\text { NRHP } \\
\text { Eligibility or } \\
\text { Significance } \\
\end{array}$ \\
\hline $\begin{array}{l}\text { NRHP Property: Los } \\
\text { Nogales }\end{array}$ & $\begin{array}{l}\text { (S. River and E. Live Oak Streets) } \\
\text { The old home was originally built in } 1849 \text { for Justus Gombert. This building } \\
\text { is an example of a primitive home with its pioneer style kitchen and sod hewn } \\
\text { cellar. }\end{array}$ & $\begin{array}{l}\text { Listed NRHP Eligible } \\
\text { Property }\end{array}$ \\
\hline $\begin{array}{l}\text { NRHP Property: Erskine } \\
\text { House No. } 1 \text { (Hollamon } \\
\text { House) }\end{array}$ & $\begin{array}{l}\text { (902 N. Austin Street) } \\
\text { Hollamon House, in Seguin, Guadalupe County, is actually two houses in } \\
\text { one. Dr. Benjamin Lea moved one part of the house to Seguin in } 1867 \text { and } \\
\text { attached it to a four-room concrete structure built by a Captain Sedy in } 1855 \text {. } \\
\text { The two parts create d an outstanding piece of architecture which was } \\
\text { given an Award of Merit by the Builders Survey of Texas. }\end{array}$ & $\begin{array}{l}\text { Listed NRHP Eligible } \\
\text { Property }\end{array}$ \\
\hline $\begin{array}{l}\text { NRHP Property: Joseph F. } \\
\text { Johnson House }\end{array}$ & $\begin{array}{l}\text { (761 Johnson Avenue) } \\
\text { Between } 1842 \text { and } 1860 \text { about ninety concrete houses and commercial } \\
\text { structures were erected in Seguin, Texas. Of those, twenty-five are extant } \\
\text { today. One of the most noteworthy in its architecture is the Joseph F. Johnson } \\
\text { House, built circa } 1847-1854 \text {. Colonel Johnson was an early settler and } \\
\text { prominent resident of Seguin. The Johnson House is a surviving example of } \\
\text { the concrete construction that was developed by in Seguin by Dr. Parks }\end{array}$ & $\begin{array}{l}\text { Listed NRHP Eligible } \\
\text { Property }\end{array}$ \\
\hline
\end{tabular}

While no cultural resources are identified within the APE on the THC-Atlas, the City identified a single grave marker located in the northwest corner of the APE. A review of historical topographic maps dating to 1911 (San Marcos 1:125,000), 1919 (San Marcos 1:125,000), 1924 (San Marcos 1:48,000), 1930 (Seguin 1:62,500), and 1953 (Seguin 1:62,500) do not depict a cemetery at this location. Further a search of the Guadalupe Appraisal District's website only indicates that the Antwine family owned the property before its recent sale to the City with no mention of a burial at this location. Given its location and ambiguity of its marker, if this area is indeed a burial, it may likely be that of a family pet. 


\subsection{ARCHIVAL AND HISTORIC RESEARCH OF TRACT WITH CISTERN}

The tract of land where the cistern was discovered and subsequently documented is listed as 520-530 Medlin Street. According to the Guadalupe County Appraisal District website (2019), Kermit and J. Antwine are listed as the property owners between 2006 and 2017 prior to purchase by the City in 2018. There are no tax records prior to 2006 on the Guadalupe County Appraisal District website. Based on Texas Land Survey data, the tract is part of the Humphreys Branch Original League measuring 4,935 acres surveyed in 1853 (Texas Railroad Commission 2019).

Property deed information was reviewed at the Guadalupe County Clerk's Office on November 19, 2019. Starting with the known property owner prior to purchase by the City, Kermit Antwine, reverse deed records were used to identify previous landowners. The earliest deed on record is dated to May $7^{\text {th }}, 1883$ (Appendix C: Deed Vol. T, Pg. 567). According to the 1883 deed, the tract was occupied by George W. West and his wife, Sara A. West, who conveyed the homestead to D. Newton. The property description in 1883 is recorded as:

....One mile N.W. of the Court House in Seguin part of the H. Branch League and being subdivisions $L$ and $M$ of part of said League as made between A. Neill and A. Swift about 30 years ago and of record in said County...portions of each subdivisions which we have heretofore conveyed to J.L. Short and to Aug Stuart. The tract herein conveyed is bounded on the $S$. by Moses Campbells old place, on the W. by the tract we sold to said Stuart. On the North by said Shorts tract, and on the E. by the Byler tract and contains about Fifty Two Acres.

The original 52 acres noted in the 1883 deed was subsequently subdivided into smaller parcels sometime in the early $20^{\text {th }}$ century. This property description is recorded in a 1981 Warranty Deed wherein Albert Elley conveyed the property to Kermit Antwine (Appendix C: Deed Vol. 616, Pg. 37-38). At the time when the property was conveyed to Kermit Antwine, the tract measured .445 acres.

After tracing the deed records backward through time, a number of previous landowners were identified. This includes: Kermit Antwine and wife, J. Antwine who conveyed the land in 2018 to the City; Albert Elley and Lola Elley; Walter Friedeck and Edna Friedeck; E.A. Weyel and Irma Weyel; R.W. Kiser and Ruth Kiser; Edmund Friesenhahn; R.W. Moffett; H. Babin; Rudolph and Augusta Tschoepe; Frieda Jandt; A.J. Fennell and Mary Fennell; W.E. Koepsel; D. Newton; and George W. West and Sarah West, the earliest landowners found during the deed research.

Subsequent to review of historic property deed information, a search of family history records and genealogical information housed at the Seguin Public Library was conducted and informed by the landowner names contained in the deed records. No genealogical information could be found for most of the previous landowners. However, a detailed genealogy of the Tschoepe Family was compiled and written in 1980 by Annette Waite, a descendent of Rudolph Tschoepe.

According to Waite (1980), Rudolph Tschoepe, Sr. was a German immigrant that arrived in the United States in 1857. In 1874, Rudolph Tschoepe married his first cousin Augusta at the First Protestant United Church of Christ in New Braunfels. Two years later, in 1876, the Tschoepe Family settled on a 230-acre tract of land near Geronimo Creek in Geronimo, Texas. Rudolph Tschoepe served as the third president of 
the Thusnelda Lodge No. 37, now Seguin Hermann Sons Lodge, in 1892. In 1911, he helped form the West Seguin Improvement Company which raised money to purchase land for the Texas Lutheran College. He also served in the thirty-fifth legislature in 1917, helped fund and organize several local industries and banks, and was on the board of directors for the Farmers State Bank in 1918. It is also noted in Rudolph Tschoepe's biography that he continued to buy and sell tracts of land throughout the Seguin area.

Direct reference is made to the property on which the historic cistern was found and documented on page 77 of the Tschoepe Family history. The property is described as follows:

\section{On September 16, 1909 Rudolph and Augusta purchased fifty two acres west of Seguin} from A.J. Fennell. Rudolph and Augusta and their two children Willie and Frieda and Rudolph's brother Wilhelm moved into the big two-story home that stood on this acreage. Live oak trees surrounded the home. In front of the home stood a red picket fence.

A well and windmill stood to the east of the home. An underground cistern held rain water for use in the home. A red brick walk had been laid from the kitchen door to the windmill, the wash house and the smoke house.

Frieda Agatha Tschoepe, daughter of Rudolph and Augusta, lived in the home on the 52-acre tract. In 1919, Frieda married Otto William Jandt. In that same year, Rudolph and Augusta gifted the 52-acre tract to Frieda and Otto Jandt. The Tschoepe Family history states:

Frieda Agatha Tschoepe was born February 9, 1885 in the home Rudolph and Augusta Tschoepe built on the family farm near Geronimo. Her entire childhood was spent here. In 1909 she moved with her parents into the two-story home that stood on the fifty-two acres west of Seguin. Ten years later on January 18, 1919 she married Otto William Jandt who was born December 29, 1885. They moved to San Antonio for a short time after their marriage. When Rudolph and Augusta retired and moved to West Krezdorn Street, Frieda and Otto and his four children by a previous marriage moved into the two-story home.

\section{Later Otto razed the two-story home and built a smaller one.}

Frieda and Otto had a florist and nursery business at their home there from about 1927 until 1947. Otto Jandt died August 24, 1940...Frieda Agatha Jandt died January 31, 1976 at the age of ninety. She was the last of Augusta and Rudolph's children.

For more detailed written accounts refer to Appendix C containing copies of selected pages from the Tschoepe Family history. No additional archival records relating to the cistern or home could be found.

Along with the family histories, an attempt was made to locate additional archival information related to the possible grave located at the northwest corner of the APE. After careful review, no further information could be found. 


\section{0: SUMMARY AND RECOMMENDATIONS}

\subsection{RECOMMENDATIONS}

Based on the visual survey of the single grave marker located in the northwest corner of the APE, the existing and on-going construction of the parking lot has and will avoid the burial. A combination of wooden planking and fencing has been erected around the grave location as an avoidance measure. Archival research indicates that the historic cistern was constructed prior to 1909 and was associated with a twostory home that at one point was located on the tract of land where the parking lot is being constructed. A detailed family history of the Tschoepe Family gives a written account of the cistern and the home. This home was razed in the early part of the $20^{\text {th }}$ century and subsequent residential construction occurred around the same time. The field visit and documentation of the cistern (41GU211) indicates that the property has been heavily disturbed by this past construction as well as active and existing construction of the proposed parking lot. In comparison to Denton's (2011) review on cisterns, this cistern is best described as a bellcistern with the base of the structure no longer intact, giving way to a large cavity in the bedrock, or as a well-cistern with construction beginning as a bell-type with the structure, complete with intake line, dug into a reliable water source. Based on the field visit and archival research, the cistern is not associated with significant review events or persons, does not embody distinctive construction characteristics, is unlikely to yield significant information important to Texas history or the history of Seguin, nor does it retain enough integrity due to years of past ground disturbance. Therefore, as the cistern offers little to no research value under Criterion D (36 CCR Part 60.4), TRC recommends the historic cistern be deemed ineligible for listing with the NRHP or as a SAL. 
This page intentionally left blank. 


\section{0: REFERENCES CITED}

Denton, Mark H.

2011 Cisterns in Texas. In Current Archeology in Texas. Texas Historical Commission, Austin Texas.

Gesick, J.

2000 Under the Live Oak Tree; A History of Seguin

(http://www.seguintx.net/heritage/gesicktree/gesicktreeabout.html). Accessed July 13, 2015. Uploaded in 2000.

Ochoa, Ruben E.

2010 Handbook of Texas Online, "Guadalupe County"

http://www.tshaonline.org/handbook/online/articles/hcu03, accessed November 18, 2019.

Texas Historical Commission

2019 Texas Archeological Sites Atlas. Electronic document. https://atlas.thc.state.tx.us/Account/Login, accessed November 2019.

Texas Railroad Commission

2013 Texas Historic Overlay: Original Texas Land Survey (OTLS) from the Texas General Land Office (GLO) maps. http://www.tnris.org/. Accessed November 18, 2019.

Waite, A.

1980 German Immigrants: Rudolph and Augusta Tschoepe. Seguin-Guadalupe County Public Library Local History Collection. Seguin, Texas. 
This page intentionally left blank. 


\section{APPENDIX A: DESIGN PLANS}




\section{APPENDIX A: DESIGN PLANS}




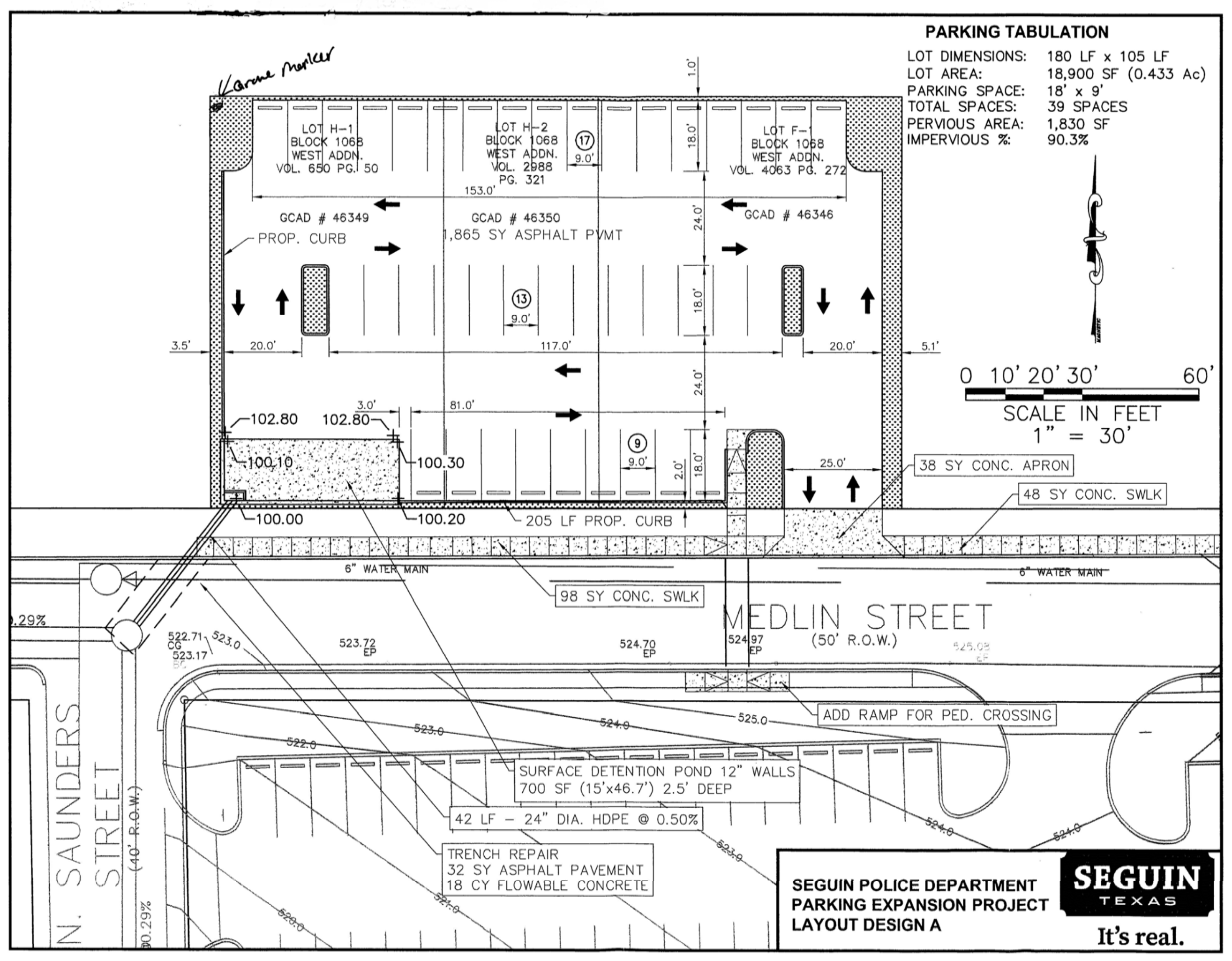


This page intentionally left blank. 


\section{APPENDIX B: THC COMMUNICATION}

Technical Report No. 315751.1000 
From:

Sent:

To:

Cc:

Subject:
Jeff Durst <Jeff.Durst@thc.texas.gov>

Friday, November 15, 2019 8:39 AM

Sarich, Steven; Haefner, Josh

Clark, Pollyanna

RE: [EXTERNAL] Re: Seguin Parking Lot Facility

This is an EXTERNAL email. Do not click links or open attachments unless you validate the sender and know the content is safe.

Steven,

Thanks for sending the update and photos. The project may proceed. For the report I would suggest some archival research to see if you can figure out if there was an obvious structure related to the cistern.

Regards,

Jeff

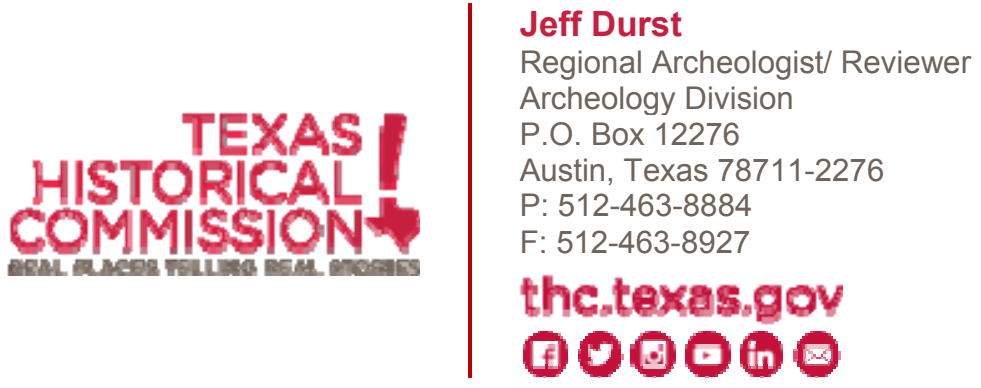

From: Sarich, Steven <SSarich@trccompanies.com>

Sent: Thursday, November 14, 2019 4:12 PM

To: Jeff Durst <Jeff.Durst@thc.texas.gov>; Haefner, Josh <JHaefner@trccompanies.com>

Cc: Clark, Pollyanna <PAClark@trccompanies.com>

Subject: RE: [EXTERNAL] Re: Seguin Parking Lot Facility

CAUTION: External Email - This email originated from outside the THC email system. Do not click links or open attachments unless you recognize the sender and know the content is safe.

$30 \mathrm{~m}$ north of Medlin St. and 111m west of N. Guadalupe St. Brick lined cistern with cast iron circular grate over top. Possibly an old iron spoke wheel. Approximately $92 \mathrm{~cm}$ in diameter. Cut stone approximately $13 \mathrm{~cm} \times 6 \mathrm{~cm}$ on average. Appears to be cut limestone. Approximately $155 \mathrm{~cm}$ neck before giving way to natural cut geology. Approximately $3 \mathrm{~m}$ deep however large amounts of gravel has dropped in. Cistern opening is $15-20 \mathrm{~cm}$ below grade. Small number of red 
brick fragments surround the cistern opening. Possibly from house construction. Drainage pipe runs into south wall. Approximately $10-12 \mathrm{~cm}$ in diameter.

To my knowledge, the area will continue to be impacted by ongoing parking lot construction including continued grading, addition of layer of aggregate and paved. Not exactly sure how far along they are in the process, but I'm sure that information can be found out. The area has certainly been heavily impacted already.

Thanks,

Steven Sarich, MS

Project Archaeologist

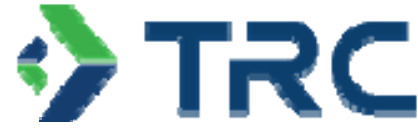

505 E. Huntland Drive, Ste 250, Austin, TX 78752

T 262.693.6182 | ssarich@trccompanies.com

Linkedln I Twitter I Blog I TRCcompanies.com

From: Jeff Durst <Jeff.Durst@thc.texas.gov>

Sent: Thursday, November 14, 2019 3:43 PM

To: Haefner, Josh <JHaefner@trccompanies.com>

Cc: Sarich, Steven <SSarich@trccompanies.com>; Clark, Pollyanna <PAClark@trccompanies.com>

Subject: [EXTERNAL] Re: Seguin Parking Lot Facility

This is an EXTERNAL email. Do not click links or open attachments unless you validate the sender and know the content is safe.

Josh,

Once the feature has been recorded if you can send me photos of the current status of the feature and a short summary of any proposed future impacts then I can determine if the project is okay to proceed prior to your submittal of the draft report.

Regards,

Jeff

From: Haefner, Josh <JHaefner@trccompanies.com>

Sent: Thursday, November 14, 2019 1:19:26 PM

To: Jeff Durst <Jeff.Durst@thc.texas.gov>

Cc: Sarich, Steven <SSarich@trccompanies.com>; Clark, Pollyanna <PAClark@trccompanies.com>

Subject: Seguin Parking Lot Facility

CAUTION: External Email - This email originated from outside the THC email system. Do not click links or open attachments unless you recognize the sender and know the content is safe.

For inadvertent discoveries, is it accurate a report on field investigations is still required for THC review before the project can return to construction?

Best, 
Josh Haefner, M.A.

Senior Archaeologist/Principal Investigator

Planning Permitting and Licensing

\section{P TRC}




\section{APPENDIX C: HISTORIC RESOURCES BACKGROUND REVIEW}


APPENDIX C: HISTORIC RESOURCES BACKGROUND DATA 
Y. Yrast oftate of Qtesas?

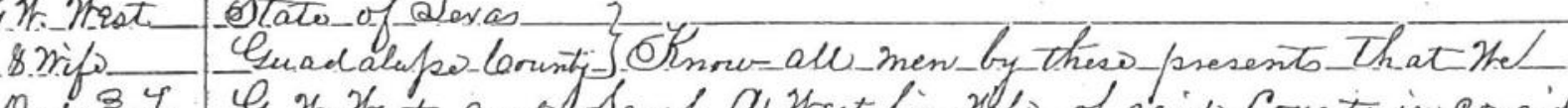

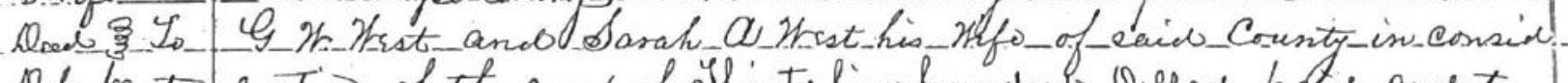

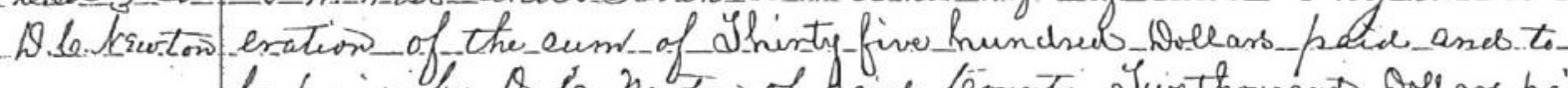

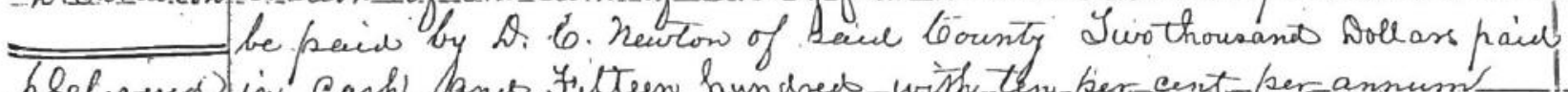

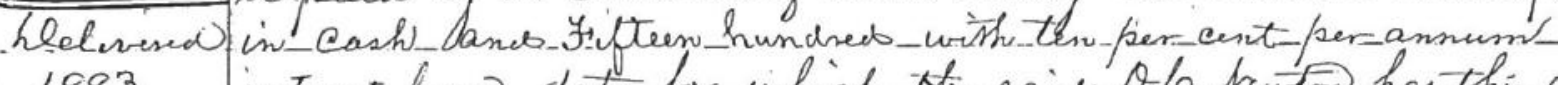

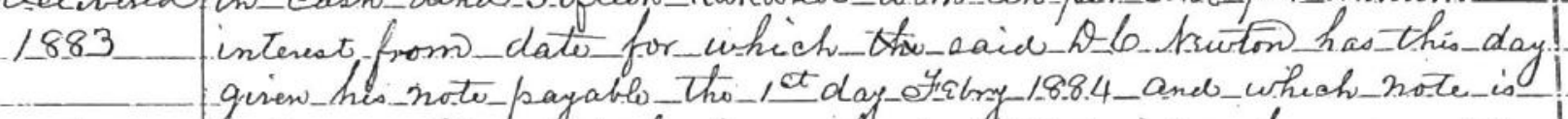

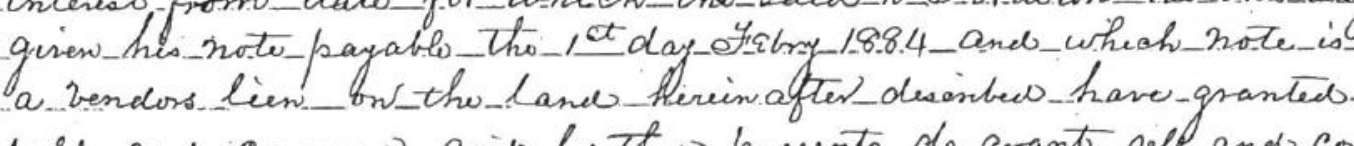
sold_and_conreyed_anib_by theso-presents_do grant sell and cont

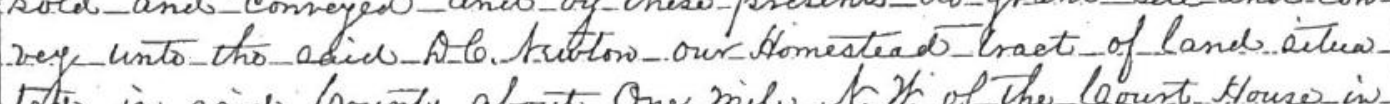

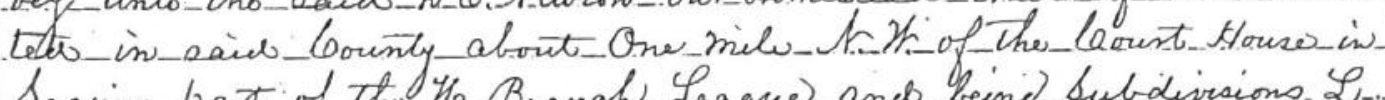
Segrien part of the Ho. Brangh League and bing Subdivsions L

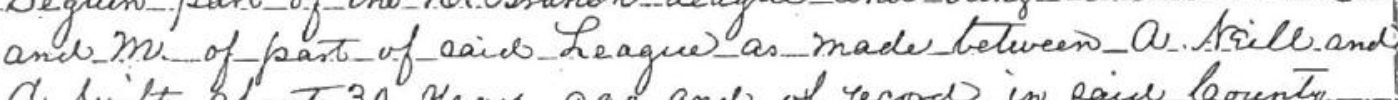
d Surft about 30 years ago and of record in Rail bounty lefo-tho portions of Each eubdivisions whech we have, heretofford conved to g L Short and to Auy twart. The Tract herein_con veyed is bundew on tho of by Omoes bamplells olv plaes

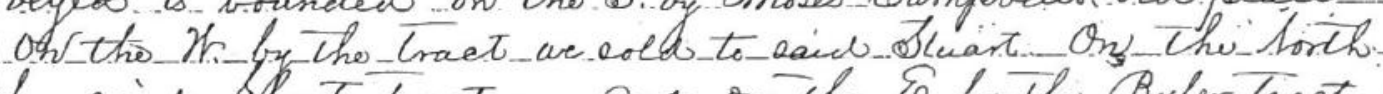
by said bhorts bact ano On_cho E by The Byler traet and contains about Hifty tur acres.,

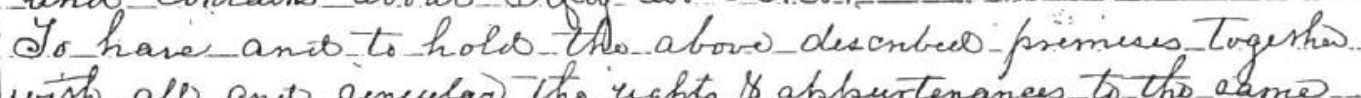
wish_alo_and_angular_tho rughto \& appurtenanes to tho a ame

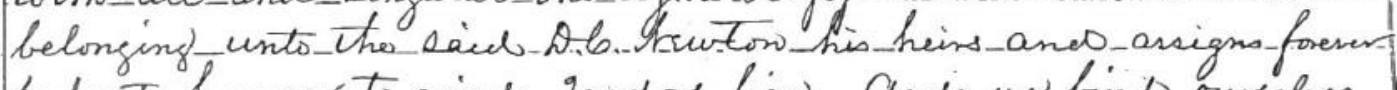
bubjet however to said Iendors_hien._And we bind oursehes our heirs executos and administratos to warrant aned forever

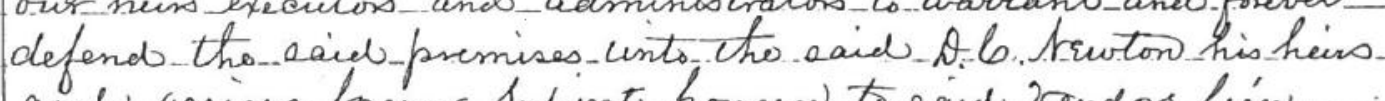
and ussigns forver buljeot howerev to eaid bendos lién Ans che bine ourselves vur hives exeators and adrienistrators to warrant and forever defend tho saul-premises unto the

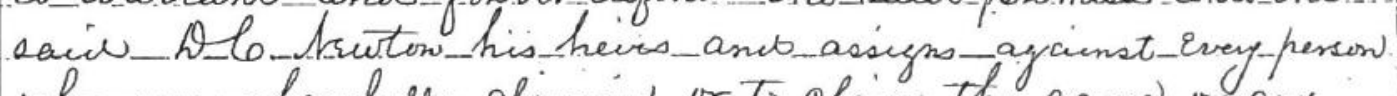
whomsusver laufully daiming or to claim the same_or any part ithereos!'

Sinefo our hands this the Tth day of may_1883 Ley If Itest orarab A. Hsit.

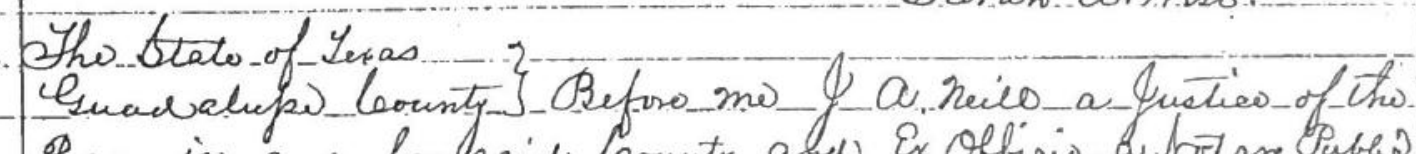

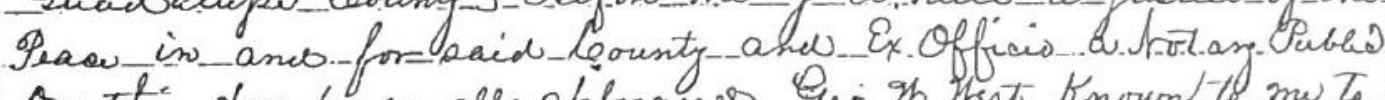

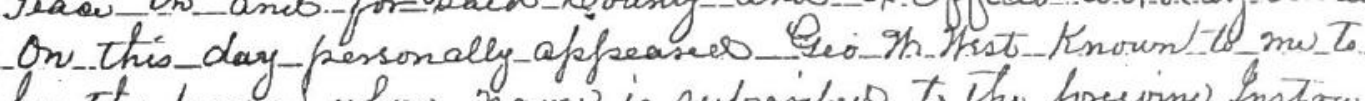
be tho person whow namw is subsiried to the foregoing instiv ment of writing aneb acknowladges to mo cthat he exeectes the

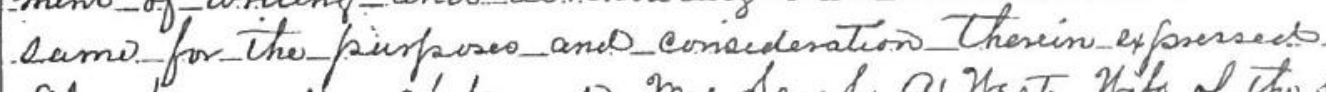

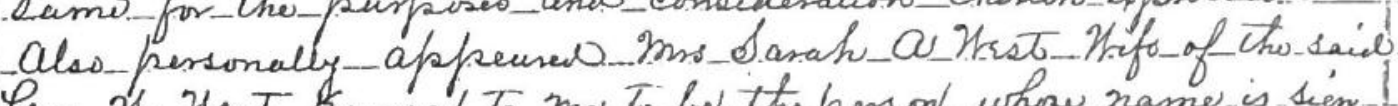
Seo H Hest Rnown to me to be thoperson whow name is Sign de to cho fregoing Instrument. of conting, and having boen Ex amined by me privily and apant from her husbands 
598

- and having tho ram fully explained to her she the racial Sarah a Hest actenowledged neh Instrument to be her act and deed and declared that She hast willingly signed tho eam for tho purposes and consideration therein expressed and that She died not -wish to retract it

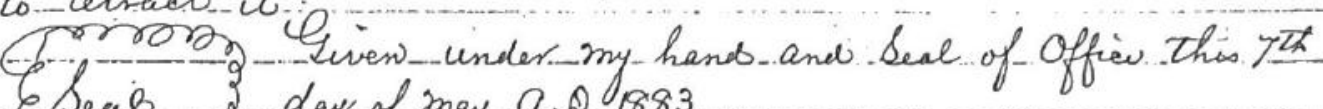

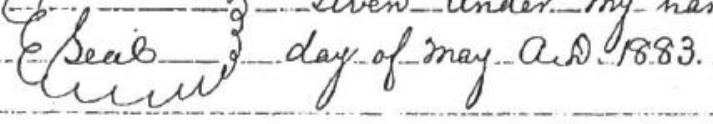
and Ex Offices trinary Public

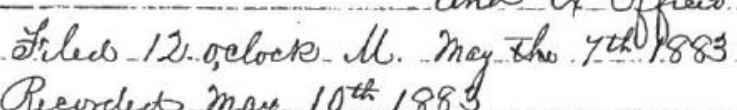
Recorded may $10^{\text {th }} 188.5$

lo. L. Arburrew, bo, lore, is

Whap Grienemect the that of Lex as?

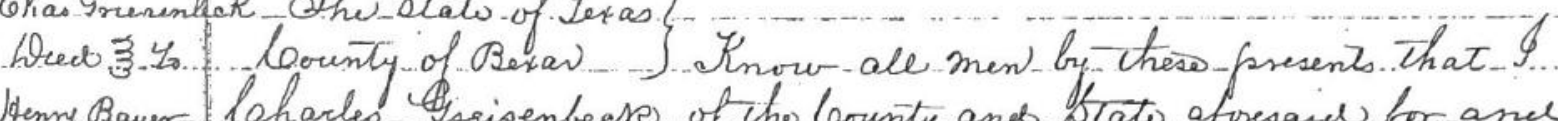

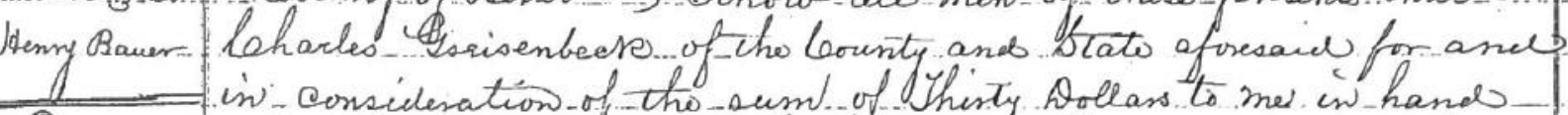

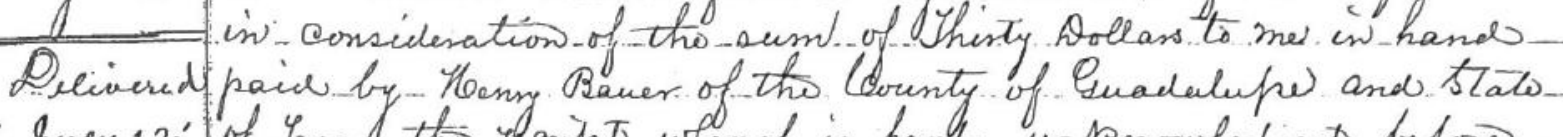

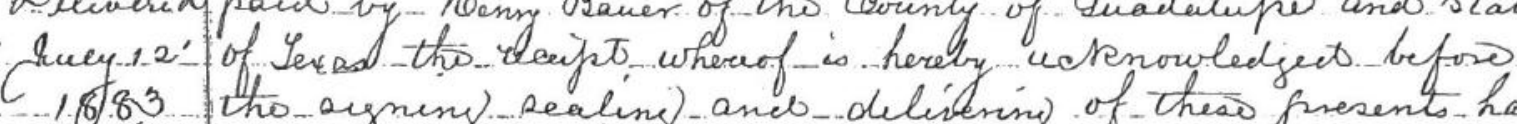
C.8.83 tho aging pealing and delivering of thess presents have) have granted bargained sold an ot released and ty. The present do grant bargain sell releaw and coney unto tho. Raid Keening Bauer his hers and assigns all that Tract or parcel of land lying and being in tho bounty of Quad allee toto of Les ab containing Six (b) acres of Land anis deseribit as follows - being a part of tho western half of bun ne

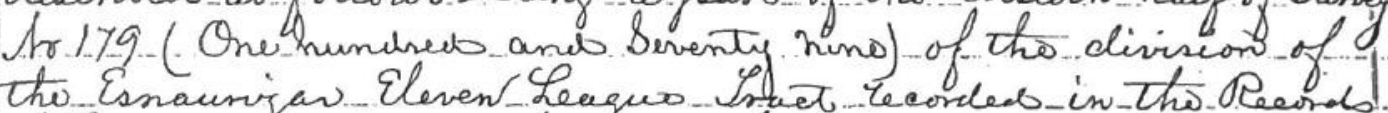

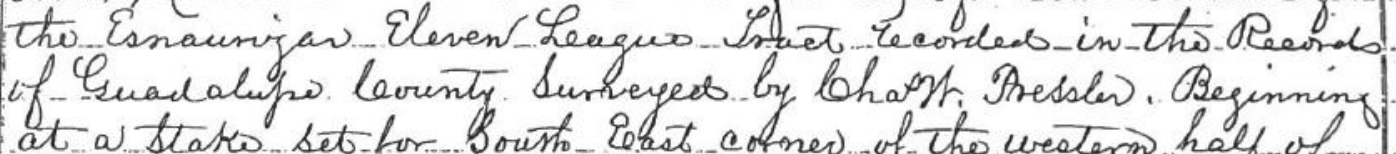
at a Stake set for South Quest corner of the western half of Survey to 1.7.9.

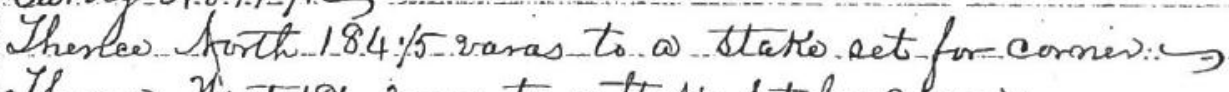

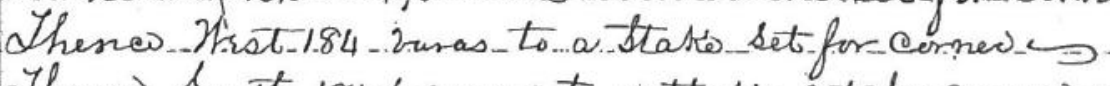
Theses bouts $184 \%$ varas to a state aet for correcoces These East 184 varas to tho places of Beginning and which

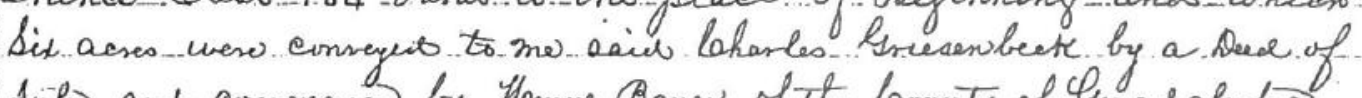

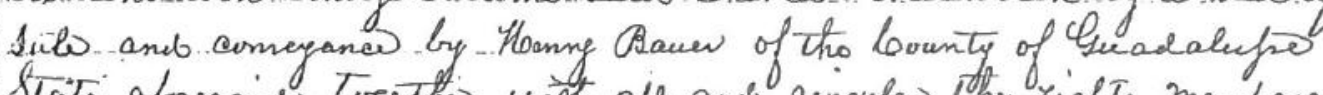
Stats -aforesaid tugethis wist all and angular the rights members hared Laments and appurten anew to tho a a mo belonging or in an g The premises above mentioned unto the said. Henry Bauer his heres and assigns forever. A no \& do hereby bond imperf Ing heirs excenters and administrators to warrant and forever. defend all ones Singular the o aids premises unto the a aid Hoeing

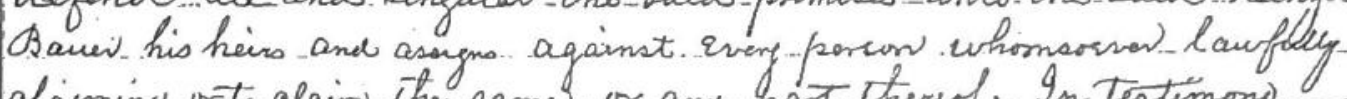
dainning-orto claim the same or any part thereof In testimony

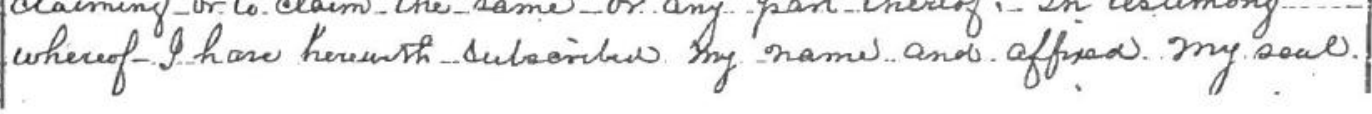




\section{4}

WARRANTY DEED

ITH STATE OF TEXAS

COUNTY OF GUADALUPE

Know all men by these presents that We, Albert Elley and wife, for and in consideration of the sum of TEN of $\mathrm{re}^{\mathrm{a}} \mathrm{s}$, and other valuable consideration to the understghed $(\$ 10,00)$ and otheres herein named, the recelpt of which $1 \mathrm{~s}$ $p^{\text {Id }}$ by acknowledged, have GRANTED, SOLD AND CONVEYED, and by nereby presents do GRANT, SELL AND CONVEY unto Kermit Antwine the wife, Janet Antwine of the County of Guadalupe and State of Texas, all of the county, Texas, to-wit:

Gusdalupe that certain part of the Humphreys Branch original Lg. in the City of Seguin and a part of 1-acre tract ct ux by Deed dated June 23, 1953. E.A. Weyel et Luadalupe County Deed Record Voi.

and recordes 623-625 described as follows:

BEGINNING at an 1ron pin set for southeast corer, being the original Walter Friedeck 1-acre southeast cornertheast corner, referred to in the First Tract of Guadalupe County, Texas in Vol. Deed Recor 586 Richard Dick Kiser to R. G. Spurrier, 374 , page being in 8 th Street South 323.0 feet beginning bertheast corner of the original Walter from the northe tract;

Friedeck 1 acr 154.0 feet to an 1ron pin set for the THENCE west 154 . being the southeast corner of southwest Spurrier First Tract referred to in the the R. G. Sp of Guadalupe County in Vo1. 374, page Deed Record Dick Kiser to R. G. Spurrier;

586 Richard 126.0 feet to an iron pin set for THENCE north corner of the east line of the R. G. Spurrier FIRST tract;

THENCE East 154.0 feet to an iron pin set in 8 th street for northwest corner;

THENCE South 126.0 feet with 8 th street to the place of Beginning, containing .445 acre. And being a 0.445 acre tract of 1 and in the Humphreys Branch Original League in the City of Seguin, Guadalupe County, Texas and being the same property conveyed by Deed dated August 17, 1965, executed by Walter Frledeck et ux to R. G. Spurrier and being recorded in Vol. 379, page 621 Deed Records of Guadalupe County, Texas.

TO HAVE AND TO HOLD the above described premises, together with all and singular the rights and appurtenances thereto in anywise belonging, unto the said Grantees, their heirs and assigns forever; and we do hereby bind ourselves, our heirs, executors and administrators to WARRANT AND FOREVER DEFEND all and singular the sald premises unto the sald Grantees, their heirs and assigns, against every person 
ล2. 616038

$$
\begin{aligned}
& \text { whomsoever lawfully claiming or to claim the same or any } \\
& \text { part thereof. } \\
& \text { Execuite this } 26 \text { day of March, } 1981 \text {. }
\end{aligned}
$$
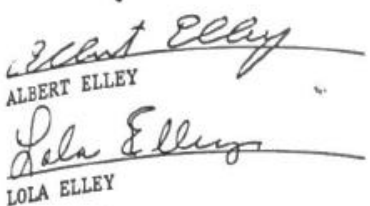

(ACXNOWLEDGMENT)

THE SIATE OF TEXAS

COUNTY OF GUADALUPE

Before ne, the undersigned authority, on this day personally appeared ALBERT ELLEY AND WIFE, LOLA ELLEY known to to to be the persons whose names are subscribed to the 10 foregoing instrument, and acknowledged to me that they executed 7 thidsame for the purposes and consideration therein expressed.

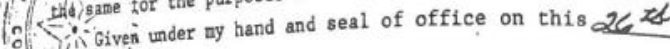

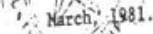

$a_{i, 1}, i^{2}$

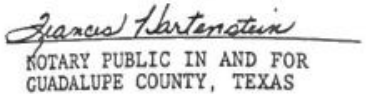

MY COMMISSION EXPIRES: $10-3 /-84$

\section{THE STATE OF TEXAS}

Ceenty of Gaadalupe

I, FRANK SCHMIDT, Clerk of the County Court in

ad for said County, do hereby certify that the foregoing instrument of writing dated the.26. day of mesch 1081 ., with its certificates of authentication, was filed for Record in my

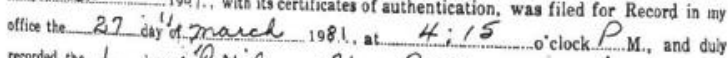
resorded the 1 da of epprie 198.1, at 9:0? o'ciock $A$..., in DEED Recourd of said County in Vol.... Lelle day and year last and the geal of the County Court of said County, at office in Seguin, Texas, the day and year last written as

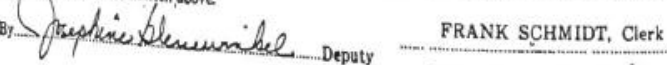




\section{For Reference}

Not to be taken

\section{from this room}

\section{GERMAN IMMIGRANTS}

RUDOLPH AND AUGUSTA TSCHOEPE

by

Annette Waite

SEGUIN-GUADALUPE COUNTY PUBLIC LIBRARY

50509010048956 
Rudolph Tschoepe, the son of Anton and his wife Susanna lenora $^{2}$ he always celebrated his birthday on October 9 the noweverthplace was in the town of New (Neu) Wilmsdorf, gis ny. (Note: his obituary.) However in listed as his lace of place is listed as Altlomnitz, (sometimes w places is birtitzl perhaps because the priest from the chritten At thomnitz baptized him. In yet other places hirch in Alt is listed as Glatz. (Glatz was the largest is birthplace is area at the time.) in the augusta Tschoepe, the daughter of Benjamin and Karoline knauer Tschoepe was born January 25, 1847 in Altwilmsdorf, (sometimes written [Alt-Wilmsdorf] Germany). 1 the sons of Joseph Tschoepe. The two families lived only a few miles apart in Germany. Many times Rudolph enjoyed the company of his younger cousin Augusta as their families gathered in their respective homes.

When Rudolph was ten his family decided to sail to merica. His cousin Augusta was five then.

Nine years later when Augusta was fourteen, her mother became ill very suddenly. Karoline Knauer Tschoepe died overnight of the bubonic plague often called the black death because of the spots that develop from bleeding under the skin.

At the age of sixteen Augusta began working at a bakery in Germany.

In America, Rudolph and his family lived for a short time in New Braunfels and then made their home on Long Creek near Schumannsville, Texas.

In 1861. Rudolph volunteered to serve in the Civil War. He served throughout the war and was paroled in New Braunfels, Texas on July $31,1865$.

Upon his return it took quite some time to help get the farm in good shape again.

With this work completed, he took up a different type of work for a short time. Perhaps it was a bit of restlessness too that made in the work of freighting. Freighters were still in demand With the arrival of more new settlers coming to Texas. anong them in 1873 was his cousin Edward Tschoepe. A lew months later Edward's sister Augusta arrived. She

come to America with friends.

was ang the treasured belongings Augusta brought with an album of ten of the most beautiful sights in

l the She name Karoline Knauer Tschoepe is reported in mother of Augusta Tschoepe. 
Glatz was quite a large industrialized
The pictures included a general view city of that the train station, a church, the courthouse, the Kaiser-Wi large fortresta and Edward's father Benjamin view toward later exception of Augusta's now. It was a happy one ${ }_{2}$ with the excll in Texas now seen each arrived. families were families who had not seen each other the two for the two fom. for over twenty years. The following Augusta Tschoepe wertant United Their cousins Rudolph and at the First Pred arriage is recorded as February 2, license number is 1084 . by a protestant minister in the They were mis parents. Their parents Anton, Susanna home of Rudol were present for the wedding ceremony. One and Augusta Blum's children was baptized at the wedding ceremony. Augusta Blum was Rudolph's sister.

After their marriage they moved to old Marion. 0ld Marion was an early railroad construction camp approximately ix miles east of the present day town of Marion. It was here that their son Willie was born in 1874. Willie as he was later called was baptized William Edward Tschoepe on June 13, 1875 at Saints Peter and Paul Catholic Church in New Braunfels. This was the church they attended while living at 0ld Marion. Two years later in 1876 a second son Hugo was born at 0ld Marion. Because of lack of good water on their place they moved that same year.

In 1876 Rudolph purchased a tract of land containing two hundred thirty and eight-tenths acres of land on the spring-fed Geronimo Creek near Geronimo, Texas. 3 This was a beautiful spot, suitable for both farming and grazing. They moved into the little two-room concrete Navarro ranch
house in August.

One hundred years later during our country's bicentennial a picture of this little home together country's bicenten Navarro and a brief history of the home were hung in the

Autunool library in Geronimo.

it was for came and they were all settled. What a thrill and geese flock that first autumn to see thousands of ducks spot seemed to be the Geronimo creek. Their favorite trees. Here they under those hugh moss covered live oak
In the ate their ${ }^{2}$ Information concerning the arrival of Augusta, Edward
Benjamin was secured from Seguiner Zeitung, October 7,1921 .
${ }^{3}$ Deed Record Book 0, Page 52, Guadalupe County, Texas. 
in the old ranch house. During this same year they wied inted of a kitchen and two bedrooms and. This home o. is $^{\text {iste }}$ The home stood near the area of and a porch. (Note: Marvin Tschoepe tractor house.) and this same year Rudolph sold a part

ge west of the Geronimo Creek to $\mathrm{J}$. ${ }_{a} c_{r}$ age wional fourteen and one-third acres from and purchased an adining his tract.

ear was 1880. He was followed in the new home. the 1882 Rudolph purchased thirty-fitz in 1881. from 1 A deed dated 1883 shows ${ }_{6}$ Rudolph purchased an additional five acres from S. M. Ewing. He paid forty dollars for the five acres.

The year 1883 was also the year the first baby girl was born in the family. They named her Louisa.

In the spring of 1884 Rudolph rode his horse into castroville to be a witness at the wedding of his sister Augusta who married Samuel Etter, Jr. on April 19 of that vear. Twenty-three years before he had ridden through Castroville on another horse as he was going to New Mexico to engage in that campaign of the Civil War.

In the summer of 1884 Rudolph's father Anton died at the age of seventy-five.

Frieda was born in 1885. She was followed by Emil in 1887. In 1887 Susanna the mother of Rudolph died at the age of seventy-five.

As Rudolph and Augusta's family increased and more rooms were needed an addition of several rooms was added to the home. To provide extra space the boys often slept in beds in the attic.

After the death of his parents Wilhelm came to live vith his brother Rudolph and his wife Augusta on the family farm.

On the farm all of the planting and cultivating was one with the use of mules. Cotton and corn were the crops he raised. All of the children worked in the field. The cotton was picked by hand and loaded on wagons and hauled to one of the cotton gins in Geronimo. Pulling corn and cutting tops were completely done by hand. The tops and orn were hauled into the barn for feeding. Sometimes rainy day was spent shucking corn in the barn.

At various times Rudolph and Augusta kept many different of farm animals.

'Deed Record Book P, Page 126, Guadalupe County, Texas. 5 Deed Record Book 6 Deed Record Book T, Page 135, Guadalupe County, Texas. 
to do the field work. Mules were kept for milk. churned her own butter, made Koch cormilk. Augustatage cheese. and buttend cheese anced to keep them supplied with hams, kogs were bute. bacon and shens were alwe for their meat too. While the grown-

Turkeys were children were in the field it was the job ups and the older to keep an eye on the turkeys. They of the little ones them around, sometimes stalking them all the had to follow the They had to find out where the nests way to the creek. were; so that as home to a safe place. She pulled the feathers Augusta raised feather beds for her family. The to make pillows anled every six weeks. The goose was generally held bottom side up with the head between her side and her arm. With the same arm and hand she held the feet of the goose. With the other hand she plucked the soft feathers. If there was even the slightest sign of blood on the quill she waited a few days longer than the usual six weeks. The feathers were put in a thin cloth sack. She usually used a flour sack. She hung the sack on her clothes line in the sun for several days. In this way the feathers dried and were ready to be made into a pillow or a feather bed.

Augusta gathered dried moss from the trees along the creek. She used this to make pillows too. One of these is still in existance today.

She always had a spring

were eaten fresh or canned.

Fruits were or canned.

The Geronim eaten fresh, canned or dried. with an aronimo Creek and surrounding area supplied them agarita, berries and food. She made jelly from wild grapes, Water cress could figs growing on the family farm. gathered and used be gathered for salads. Pecans were her with fish for the family. Many times the boys supplied Aside from cooking family dinner table. from those heavy ing the meals for her large family and She mall for the pots she had to draw all the water She sewed ade her own soas, clothes and family baths. find ingenil the clothes which was always a messy ther perishab cool places for her own family. She had to kept her house les. She kes to keep the milk, meat and the din she was alwith wit an eye on her children and she died and the was always in all of her work and very few buried in 1890 , Bood spirits. Seguin. 
fumertime found Rudolph taking the boys to the creek
inming. Rudolph, as well as the boys, enjoy Augusta and the girls never enjoyed enoyed

ming. got in the creek once to wash somed swimming. gil $g$ in too deep and almost drowned. This wathes. shey got time they went.

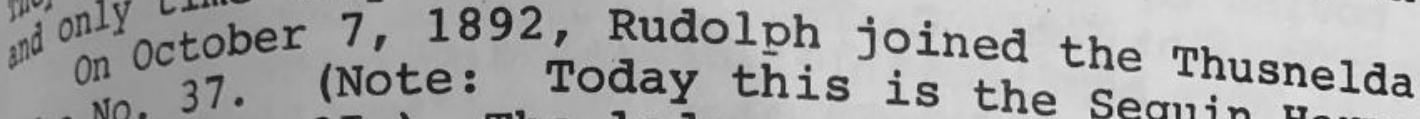

No. 37. (Note: Today this is the Seguin Hermann jolge lodge No. 37. molph ser as ... their president and server. During the bicenten at alternate times hereafter. Dures of past presturial celebration of our wutry, pictore were hung presidents including one of 1olph Tschoepe we lo in Seguin.

In 1894, twenty years after the first-born, walter as born. At the time of his birth Augusta was fortyseven and Rudolph was fifty-two.

Two other children born to Rudolph and Augusta died and were buried on the family farm. Anna and an unnamed infant were buried in unmarked graves. (Note: Today this is in the area of the Tschoepe-Harborth fence line south of the old Tschoepe home.)

As additional land adjoining Rudolph's farm became arailable and as his funds permitted he increased his acreage. Such was the case in 1894 as he was able to purchase an additional eighty-four and fifty-seven one tundreds acres from George Schmidt. 7

In 1899 Rudolph purchased one hundred and eleven acres from B. F. Schmidt, et al for four thousand seven hundred dollars. 8

Augusta was kept extremely busy with her family.

for three consecutive years she never left the farm go to town. Rudolph did all the shopping.

In the spring of 1902 on at least one such shopping trip misfortune struck Rudolph. This story appeared in local newspaper: "Mr. Rudolph Tschoepe's roan horse and ggy were stolen in broad daylight at 10 o'clock on Wuare, morning from the west side of the court house He had come to town and had put several purchases adoped was . The thief was a bold one though the plan aty from was a safe one from its very boldness. A is horse and Vernia on Wednesday stated that he saw time." 9 , buggy being driven

'Deed Reco'rd Book 7, page 400, Guadalupe County, Texas. BDeed Record Book 14, page 292, Guadalupe County, Texas.

${ }^{9}$ Seguin Enterprise, March 14, 1902, microfilm, seguin
lupe County Library. 
weeks later the 10cal paper reported this good few weeks Rudolph Ischoepe's last Saturday. It had ns: "Mr. Tobin at San Antonie and never called for."10 by sheriff at a livery struck the family as little eight year

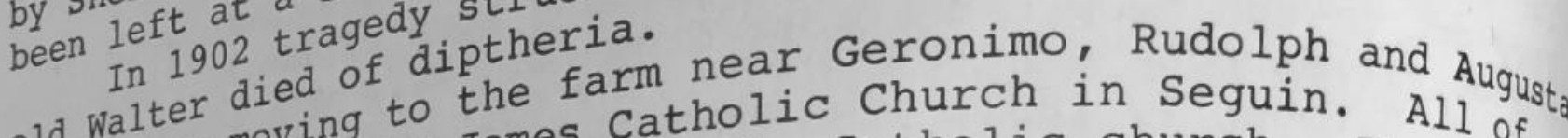
old wafter moving to James Catholic Church in Seguin. All of began attending Sain baptized in the Cathere walter was buried. Was in their children wetery in sequin that Waltenity, Rudolph the Catholic need for a church in the community, Rudolph was one of the original contro in 1904 . Church near Geronime the years of 1909 and 1911 Augusta and sometime betwe decision to join the German Evangelical (Note: Today this church is known Cross Congregation Church of Christ.) This church was organized in seguin in 1909. They remained members of this church until their deaths.

Rudolph always had time to listen to his fellow man -like the man who always walked around with a goat following him. He had killed a man in Seguin and had come to ask for Rudolph's help.

Hugo came down with malaria fever and was sick much of the time. Believing that the hill-country climate would be better for him, Rudolph purchased a ranch at Dripping Springs and Hugo moved up there. Willie spent some time there with him too. They raised horses at the ranch. Occasionally the brothers would ride them to Geronimo at a fast pace and then walk them to cool them down before they got
to the farm.

On September 16, 1909 Rudolph and Augusta purchased Rudolph and

Frieda and Rudosta and their two children Willie and two-story home that brother Wilhelm moved into the big surrounded the home stood on this acreage. Live oak trees to the front of the homere was a red brick walk leading red picket fence. An underground windmill stood to the was the brick walk htern held rain the east of the home. windmill, the had been laid water for use in the home.

Their grane wash house from the kitchen door to

they had so much ildren fond and the smoke house. climb bister on fun there. fondy remember the home because they picked wimill. indoor stay enjoyed sliding down Seguin Geguin Enterprise, April 4, 1902, microfilm,
Texas. Deed Record Book 32, page 610. gio, Guadalupe County, 
painted floral designs decorated the corners of In the center was a hand painted nome. in diameter. A similar design appearcle about feet the upstairs east front room. ppeared on the ij ing of thirs the fireplace mantel was laid with a Downseen tile.

The home did not have window screens. Mosquito nets draped over the bedsteads of each bed. The net was ere under they tucked in the fourth and after they

wall there was a coffee

Augusta ground fresh coffee before each meal. in meal of the day was always served at noon. It ways began with soup served in those bowls with the idm. After the main course there was always dessert. ecause of her early experience of working in a bakery in cemany she was able to bake extremely good pastry. One ther specialities was tomato pie.

some kind of pastry was always served as a snack in the afternoon with coffee for the grown-ups and milk for the youngsters.

on their farm they raised cotton and corn. Mules, borses, cows and chickens were kept there too. While living here they never owned a car, just a horse and buggy.

Every Wednesday and Saturday Rudolph or Frieda would $g 0$ to town to deliver butter and eggs to Louisa Hagn and ter family. They also sold them to private customers and to Seligmann's Store.

Saturday was also the day all the curious young mes gathered around Wilhelm as he shaved with the straitsige. He shaved once a week and Saturday was the day and they were always there to watch and to giggle.

In 1910 Rudolph deeded half of his 350 acre farm to is son Rudolph Louis and his wife Martha. About this too he deeded the other half to his son Emil. ore his marriage, Emil made his home with Rudolph is and Martha so the two brothers could continue to the family farm.

By the end of 1910 Hugo, Louisa, Edward, Fritz,

in and Emil were married.

in 1911 after the death of her husband Louisa Hagn Rildren Elsie and Helmuth moved into this home dolph and Augusta and their family until 1914. hulph was a very generous and kind-hearted person. both relatives and friends. When times were ny men made great financial gains by foreclosing on repay borrowed money. Rudolph at th position to lend money to many peopleople instances they would just let him secure goods 
stores in exchange for the money he had lent He kept a ledger wer than foreclose, in many instance had lent each on their names called upon to help families in he just struck he was callene instance Rev. Nick Frueh called sometim In at least olp. During bootlegging days an trouble too to seek his to Rev. Frueh. They were in great on Rudolpamily had come and clothing. The father had gotten entire lacking both foo with his bootlegging operation and need lackious trouble wudolph was able to come to the family's was put into jail. aid.

In 1911 several men from Seguin formed the West Improvement Company texas Lutheran College. Among the men was Rudolph Tschoepe.

In 1916 Rudolph began campaigning for the eighty-third district seat in the Thirty-fifth Legislature. He was elected and began serving in 1917. Those who served during the Thirty-fifth Texas Legislature were engaged in various occupations. There was a physician, a contractor, a music dealer, a hog raiser, a brewer, a bee keeper and a minister of the gospel. There were merchants, bankers, lawyers, publishers, printers and farmers. Rudolph was among the thirty-three farmers who served.

Rudolph helped organize or supplied some of the capital for the local ice plant, cotton seed mill, creamery and two of the banks. He served on the board of directors of the Farmers State Bank. A report of the annual meeting in 1919 read like this: "The annual meeting of the Farmers State Bank was held Tuesday, January 14.
"The following officers

President, Drowing officers were elected: George Hagn, Vice-president N. A. Poth, Vice-President; Max Starcke,

"Rudolnt and cashier.

Breustedt, Hútschoepe, Sr., Ferd. Bading, Mrs. W. A. Timmermann, Directors. $\mathrm{H} . \mathrm{H}$. Weinert and William
"A dividector.

surplus fund and was declared, an addition was made to the

a bank for is an exceptiona carried as undivided profits. "We call first year.

now a member attention

so honored in the board the fact that one lady is Seguin Ghe Seguin Enterprise, January 17,1919 , microfilm, 
All the while Rudolph and Augusta continued living on ne farli. afternoon naps and they had to be very on the farm. there Wpa Rudolph would always rest on the bed whil quiet. jran a would nap in her rocking chair. First she Grandma Hug a the paper; as she fell asleep it would fall would lap and slide on floor coloring The grandchildren would lap lying on the floor coloring or reading. With their ver their noses they would giggle and giggle "rather hands uietly." This was because as she slept she would nod her head and the end of the year 1919 she was cooling soup. By the endire. They moved Rudolph and Augusta had decided to retha Schadwitz at 314 into the home of Rudolph's sister Agathember of that year. Krezdorn in Seguin. Agatha died in Novemas now married and this time daughter prieda who was now married and living in San Antonio moved back into the two-story home with her husband and family.

About this same time Willie left home. He bought a ranch next to his brother Hugo's ranch near Dripping springs in Hays County. For awhile he lived with Hugo. Rudolph, Augusta and Rudolph's brother Wilhelm enjoyed the comforts of this home and its location during their retirement.

Augusta really enjoyed an electric iron. It made her work so much easier. Previously she had used the heavy irons that were heated on the stove or with charcoal from the coal furnace. No longer did she have to rub the heavy irons over a piece of green cedar on a piece of thick duck cloth to keep them smooth and clean. They had served another purpose too, at night she heated them, wrapped them in a heavy cloth and put them in their beds to keep their feet warm.

They had a garden, fruit trees and a grape arbor.

his family's use Rudolph made wine.

in the back yard stood a wash house. At the time the in not have a filtering plant. A filter on their ain kept their water from being cloudy after a heavy

In the back yard there was also a chicken house. Hens kept for eggs. Whenever weather permitted Wilhelm walked to the
holic and Methodist churches. He attended Cross Evan-
ical and ind and Reformed Church with the family on Sundays Al a while. Although deaf and mute, he learned to speak so the
foly could understand him. Whenever it thundered he could
the the vibrats vibrations and would say, "der Himmel Vater bu with numberly Father is angry). He kept himself me milk
ttles of chores. Each evening he put the empty to
ck on out to on the porch. In the mornings he went out to that used in the stove for winter heating. 
hought a four-door Model $T$ Ford. He never
here able to take him it, but his grand and his friends to various places Rudo but his him him and Hilmar took him to the Con-
drove it, Elsie took Helmuth and
places. Dan, Hen at Camp Ben McCulloch at Driftwood, in sederate reunions at che would walk to town at Texas. Rude and sometimes the exercise. least once ase he liked the prink wagon came down the streets rides because a week a sprine gravel streets. The wagon Twice the dust of the drawn by mules. For fifty with the big water drum en this service in front of their cents a month home.

In the spring of 1921 Augusta became ill. In hopes that the pure clean hill-country air would be good for that the pure clean went with her to the Altenheim der
her health Rudolph werme for the Aged) in
Hermanns-Soehne (Hermann Sons Home for comfort, Texas. They stayed for a short time and returned home.

With all of the special care she received in Comfort and from her family at her home at 314 Krezdorn she was unable to make a full recovery. She died September 29, 1921 at the age of seventy-four years. Rev. H. Barnofske officiated at the service and the Cross Church choir sang the German hymn, "Ueber den Sternen." She was among the first women to join Der Frauen Verein (Women's Union) at Cross Church. She was buried at the Riverside Cemetery.

Pallbearers were friends of the family. They included William Schriewer, Fritz Schriewer, Peter Scheler, Mike Klein, Ferdinand Klein, August Glenewinkel, Max Werner and Wilhelm Weinert.

After her death

with their niece Rudolph and Wilhelm had their meals Then in children Elśie 2 Rudolph's daughter Louisa Hagn and her Krezdorn into and Helmuth moved from their home on East and Wilhelm. the home at 314 West Krezdorn with Rudolph

During

and visits the next few years Rudolph he sat in his his family. With his ready smile rocking chair chatting with them which forgetting hile he welcomed his grandchildren. Street. He krezdorn andion and birthdays he would walk which she Here he once pur son Jewelry on East Court for the watch for has today, others too. ka and several rings for Anita, a of course appropriate gifts 
sometimes he would take them with him on his daily
Anita once walked across town with him to his k5. 1 amon who lived in a home overlooking to his friend sometimes he picked pears or peaches with thalupe rer. ck yard so they could have them to enjoy. is back continued to be interested in education.

ys visited his grandchildren's school at San He always the public was invited to come. He watcheronimo thenevildren perform at the blackboard as they wer his gralided to answer questions and work problems.

In 1929 Rudolph's granddaughter Elsie Hagn who lived he home at 314 his suitcase married Eugene Naumann. in the just brought his suitcase with his belongings and noved right in.

In his late years Rudolph became feeble and needed wtra care. Although he still enjoyed his daily walks he sometimes became confused about the direction of his The Grein twins, Lucille and Cecelia who lived nearby often kept an eye on him and would lead him back home. As it became necessary to have extra help Bettina schubert came to live in the home. Later his son Willie came from his ranch to help care for him.

Sadness filled the home at 314 West Krezdorn when Rudolph died on March 17, 1932. As was the custom in those times the coffin stood in the home of the deceased. Priends and relatives came to the home to view the body. The family kept this tradition as well as a wake. His friends and neighbors kept the vigil. Mr. Herman Schriewer, Vr. Arthur Weinert, Will Koch, and Rudolph Woelke took turns staying throughout the night.

The funeral was held on Friday, March 18 at the Goetz Puneral Home with interment in the Riverside Cemetery. The officiating ministers were Rev. Theo M. Janssen and lev. Joseph Jaworski.

During the funeral his brother wilhelm died of neumonia in his bedroom. A nurse Mrs. Irma Arnold had come to care for him the previous night and the day of is brother's funeral because others in the home were . Ill with influenza in the home at the time were dettin's daughter Louisa, her daughter Elsie and na schubert.

So it was that these two brothers who had always been close companions during their entire lives now met their deaths within a few days of each other. Relatives and mut remarked that perhaps it was the wish had shown such massion for him all of these years. Wite Rudolph and wilhelm's deaths and Rudorants of seph Tschoepe'sore them the German born ind. 
lives they had sailed across the ocean
During their liven horses thousands of miles. They a sailing the country rogy and finally the Model T Ford, had walke horse and bater from a well and later with the ridden the drawn their wad the use of water in their home. They turn of cook over the opedived by the light of candles and had cooker. They had the use of electricity. They had lamps and finally wo room ranch house and once in a grand twolived in

While Rudolph rendered his services to his community, his state and his country, Rudolph and Augusta shared a life of hard work to provide the necessities for their large family. 
Frieda Agatha Tschoepe was born February 9, 1885 in the nome Rudolph and Her entire childhood wats spent here. In 1909 she moved with her parents into the two-story that stood on January 18, 1919 she married Otto William years later on born December 29, 1885. They moved to San jandt wo for a short time after their marriage. When Antonio and Augusta retired and moved to West Krezdorn street, Frieda and Otto and his four children by a p vious marriage mandt was born in this home. Later Otto clarence otwo-story home and built a smaller one. razed the twieda and Otto had a florist and nursery business at Frieda there from about 1927 until 1947. Otto Jandt their home the 24, 1940. Frieda enjoyed gardening and reading. Frieda Agatha Jandt died January 31, 1976 at the age of ninety. She was the last of Augusta and Rudolph's children.

Clarence Otto Jandt was born January 9 , Help Church in September 10,1947 at Our Lady Angela Katherine Fey who Selma, Texas he was married the served in the United States was born April 26, 1922. He served on June 30, 1962. From Air Force and retired from servivil service at Randolph 1965 until 1978 he worked in Cingela attend Saint James Air Force Base. Clarence an Seguin. Four generations of Tschoepes Catholic Church in seguin. have lived on the land children: Clarence and Shirley. They have two childre Jandt, Jr. (born November 8, 1948)

Clarence Joseph Jingleton (born August 14, 1948). married Patricia Ann philip Joseph Jandt (born March 11, They have one son: was born in Germany in 1976, the year 1976). Phillip was bonial. It was also the year that of American's bicentennilada Tschoepe Jandt, the last of his great-grandmother the first born. (born December 7, 1951) married Tschoepes diey Ann Jandt (boptember 8, 1951).

Shirley Att (born September Emilie Bulgerin Jandia Bulgerin Jandt died in childbirth Emilie Bulger. Emilia Bulgerin
Frieda Jandt. Frieda loved these children and treated them
in 1918 . like heroy. Jandt was born July 1, 1908. On August 11, and Elrivira Jandt was bork Voigt who was born June 27, 1926 She married Herman vore married in Seguin. She is a housewife 
living on the far they celey 1976 the ROy 19, 1928) married Viola
seguin. Ine son: They have on voigt (bor 1926). Tr. Janice Voigt (born July 14, Le Roy March 20, Le Roy Jr. (born May 14, 1947). Janice strey (born Lou and Le Jentsch Christie Gayle Jentsch Janice, Married James A. Jildren: Jentsch (born April 12, 1972) 1947) mart have three David J. Jentsh 22, 1977). Mary Lou and James 23, 1969), Dch (born Marchied Carroll Jackson and Jeremy wade Jents 2\$, 1950) married Carroll have two voigt (born October 1 . Mary Lou and October 24, 1974) and (born April Carl Lee Jackson (born 26, 1976). Le Roy children: Cackson (born October 1953) married Cynthia Ann cory Wayne Jackn December 23, They have one child: voigt, Jr. (born July 24, 1958). Thesta 20, 1977). Vanessa Ann Voigt (born Au July 12, 1910. On Februairy 28, Marvin Jandt was 1933 he married Madelined in Gonzales, Texas. During 1909. They were marved in the armed forces in Mississippi. World War II he served in the aroyed as campus engineer at Texas Lutheran College in seguin. He is semi-retired and serving the college on a part-time basis. They attend Emanuel's Lutheran Church. They have one daughter: Madeline Jandt.

Madeline Jandt (born July 28, 1941) married Karl Krueger (born May 23, 1946). They have one son: Karl Marvin Krueger (born October 11, 1978).

Herbert Homer Jandt was born January 31, 1914. In 1941 he married Nell Smith. He served in the United States Aattle for four years and was killed April 18, 1945 in the in Margraten, Bulge along the Elbe River. He was buried in Seguin, Holland and reinterred at Riverside Cemetery Elroy Jandt on May 4, 1949. Glendora Ebert was born February 2, 1918. He married married September 25 , born June 3, 1922. They were in Seguin. Guam. He is emp. He served with the Coast Roskil They have two loyed by Williamson's Nursery Steven Jandt (born children: Rosalie and Steven. Jandt (born January 1, 1945).

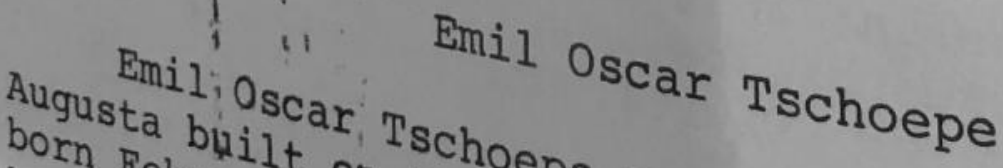

hundrebruary on the fope was hom 